\title{
VJERSKE PRILIKE U HUMSKOJ ZEMLJI (STONU I RÂTU) U SREDNJEM VIJEKU
}

Milenko KREŠIĆ

Katolički bogoslovni fakultet

Josipa Stadlera 5

$\mathrm{BiH}-71000$ Sarajevo

E-pošta: milenkokresicl@gmail.com
UDK 27-772(497.5/.6)"04/14" $94(497.5 / .6) " 04 / 14 "$ $322(497.5 / .6) " 04 / 14^{\prime \prime}$ Izvorni znanstveni rad Primljeno: 23. veljače 2016 Prihvaćeno: 8. lipnja 2016.

\section{Sažetak}

Prostori Humske zemlje do kraja 12. stoljeća bili su u jurisdikciji stonskoga katoličkog biskupa. Krajem 12. stoljeća, kad je Humska zemlja došla pod vlast kneza Miroslava Nemanjića, stonski biskup je prognan. Osnivanjem srpske pravoslavne arhiepiskopije 1219. godine ovi prostori dolaze pod utjecaj istočne Crkve. Zbog nestabilnih političkih prilika humski episkop sjedište eparhije sredinom 13. stoljeća premješta u manastir sv. Petra na Limu. Sredinom 80 -ih godina ponovno dolazi do imenovanja stonskih biskupa te ovi krajevi dolaze pod utjecaj zapadne Crkve koja je priznavala različitost jezika i obreda. Kad su Ston i Rât došli pod vlast Dubrovčana, dolazi do velikih promjena. Dubrovčani, želeći stanovništvo Stona i Râta što više vezati uz "Republiku" i ujedno zapriječiti stonsko-korčulanskom biskupu vršenje njegove jurisdikcije na Stonu i Râtu, dovode strane svećenike i franjevce (strance?) Bosanske vikarije koji uvode "rimski" obred i latinski jezik u bogoslužje.

Ključne riječi: Humska zemlja, Stonska biskupija, Humska eparhija, zapadni i istočni obred, katoličanstvo i pravoslavlje. 


\section{Uvod}

Tematika vjerskih odnosa u Humskoj zemlji (Stonu i Râtu) u srednjem vijeku često je zaokupljala pažnju povjesničara počevši od kraja 19. stoljeća do današnjih dana. Kako se Humska zemlja nalazila na razmeđu Istoka i Zapada, Katoličke i Pravoslavne crkve, hrvatskoga i srpskoga povijesnog prostora, te kako je bila pod vlašću i jednih i drugih i pod utjecajem i jedne i druge Crkve, ova je tematika zaokupljala pažnju i "istočnih" i "zapadnih" povjesničara "maloga humskog svijeta" i njegova okruženja. Prvi je ozbiljnije na ovomu polju zabrazdio Konstantin J. Jireček, potom je nastavio Nikodim Milaš kojemu je odgovorio Antun Liepopili te plejada povjesničara koji su se bavili ili se doticali ove tematike. U novije vrijeme izravno su se njome bavili na "Zapadu" Ivica Puljić i Dijana Korać, a na "Istoku", koliko je bilo dostupno spoznati autoru ovoga rada, Siniša Mišić. ${ }^{1}$ Tematika je s povijesnoga stajališta doista iscrpno obrađena u smislu da do sada poznati izvori jedva mogu što novo ponuditi, međutim, mišljenje je potpisnika ovih redaka da u njezinoj obradi nisu bile dovoljno vrjednovane ondašnje crkvene prilike, osobito zakonodavstvo zapadne Crkve i unutarcrkveni odnosi na dubrovačkome području s kojega nam dolazi najveći broj izvora koji govore o vjerskim prilikama u Stonu i Râtu 30-ih godina 14. stoljeća što se analogno može primijeniti i na ostale dijelove Humske zemlje. Ovaj je rad pokušaj da se poznati izvori još jednom preslože u spomenutom crkvenom kontekstu što je na kraju rezultiralo različitim pogledom od većine dosadašnjih autora s obzirom na vjerske, odnosno crkvene prilike u Humskoj zemlji (Stonu i Râtu) u srednjem vijeku do 30-ih godina 14. stoljeća.

\section{Opće naznake crkvenih prilika u Humskoj zemlji od 10. do 20-ih godina 13 . stoljeća}

\subsection{Stonska biskupija, biskupi i jurisdikcija}

Do početka 20-ih godina 13. stoljeća prostori Humske zemlje ${ }^{2}$ bili su pod jurisdikcijom zapadne, odnosno rimske Crkve. Pastoralnu skrb o

1 O Mišićevoj knjizi Humska zemlja u srednjem vijeku, Beograd, 1996., pogledati osvrte: Mladen Ančić, Na rubu Zapada. Tri stoljeća srednjovjekovne Bosne, Zagreb, 2001., str. 143-146; EsAd KurTović, "Paralelna historiografija (O nekim devijacijama u historiografiji: Povodom knjige: Sinıša Mišıć, Humska zemlja u srednjem vijeku)", u: Prilozi, 35, Sarajevo, 2006., str. 171-199.

2 Nije nam namjera ulaziti u raspravu o istosti ili različitosti pojmova Hum i Zahumlje. Sintagmu Humska zemlja koristimo samo u smislu jurisdikcijskoga prostora stonskoga biskupa. O pojmovima Zahumlje i Hum, o političkim tvorbama, nji- 
stanovništvu ovih prostora vodila su dvojica biskupa: stonski i dubrovački. Prvi siguran spomen Stonske biskupije susreće se u aktima Splitskoga sabora 928. godine. ${ }^{3} \mathrm{U}$ spomenutim aktima biskupija se spominje kao već postojeća što znači da njezino osnivanje, odnosno obnovu treba tražiti prije toga. Povjesničari, koji su se temeljitije bavili ovom tematikom, smatraju da je biskupija nasljednica stare Sarsenterske biskupije koja je bila osnovana na Drugom Salonitanskom saboru 533. godine. ${ }^{4}$ U kasnijim izvorima, od 11. do sredine 13. stoljeća, spominje se kao biskupija "zahumskoga kraljevstva", odnosno "humske kneževine". ${ }^{5}$ Koji je točno prostor obuhvaćala povijesni izvori ne preciziraju. Ono što se zasigurno može prihvatiti jest da je obuhvaćala prostor Zahumlja, odnosno Humske zemlje u primorju od Rijeke dubrovačke do ušća Neretve uključujući Pelješac a u unutrašnjosti prostor s lijeve strane rijeke Neretve, tj. prostor od Blagaja, preko Dabra i istočnih granica Popova do Rijeke dubrovačke. Ostaje problematično je li jurisdikcija stonskoga

hovoj sinonimnosti i različitosti, prostoru i granicama postoje različita mišljenja. Pogledati više u: Veljan TrPKović, "Humska zemlja" (ćir.), u: Zbornik Filozofskog fakulteta, VIII-1, Beograd, 1964., str. 225-260; Rudolf Bonić, "Porfirogenetovo Zahumlje i Dukljaninova Chelmania", u: Radovi Hrvatskog povijesnog instituta u Rimu, III-IV, Rim, 1971., str. 23-59; PAvo Žıvković, "Pregled političkih prilika u srednjovjekovnoj Humskoj zemlji", u: Povijest hrvatskog Počitelja, Čapljina - Zagreb, 1996., str. 11-14; PavaO AnĐelić - Marijan Sivrić - Tomislav AnĐelić, Srednjovjekovne Humske župe, Mostar, 1999.; M. Ančıć, Na rubu Zapada, str. 149-151; Mladen Ančić, "Ranosrednjovjekovni Neretvani ili Humljani", u: Hum i Hercegovina kroz povijest, I., Zagreb, 2011., str. 270-273.

3 Zaključci Splitskoga sabora 928. u: Jakov STIPIŠıć - Miljen ŠAmŠAlović (sakupili), Marko Kostrenčić (prir.), Codex diplomaticus regni Croatiae, Dalmatiae et Slavoniae, (dalje: Codex diplomaticus), I., Zagreb, 1967., str. 37. Druge je sveske priredio Tadija Smičiklas.

4 Ante Dračevac, "Srednjovjekovna Stonsko-zahumska biskupija", u: Tisuću godina Trebinjske biskupije, Sarajevo, 1988., str. 83-86; IviCa PuljIć, "Stonsko-humska biskupija i počeci kršćanstva u Humskoj zemlji", u: Hercegovina, 8-9, Mostar, 2002./2003., str. 23-30; IviCA PuljIĆ - Ante Škegro, "Sarsenterska biskupija", u: Povijesni prilozi, 30, Zagreb, 2006., str. 39. Puljić i Škegro s poprilično uvjerljivim argumentima antički Sarsenterum, te time i sjedište Sarsenterske biskupije, lociraju u današnji Stolac. O tome s dotadašnjim istraživanjima Sarsenterske biskupije pogledaj: I. PuljIĆ - A. ŠKegro, "Sarsenterska biskupija", str. 7-50.

5 O spominjanju Stonske biskupije u "zahumskom kraljevstvu", odnosno u "humskom kneštvu" pogledaj: Bule papa Benedikta VIII. iz 1022. i Grgura VII. iz 1076. koje potvrđuju metropolitansko pravo dubrovačkoga nadbiskupa "in regno Lachomis", odnosno "in regno Zaculmi", Codex diplomaticus, I., str. 61, 143. Toma Arhiđakon i Historia salonitana maior pišu da je u Stonu bila biskupija s jurisdikcijskim prostorom u Humskom kneštvu: "In Stagno nihilominus fuit episcopatus suaque parochia erat in comitatu Chilmie." Citirano prema: Ivica PuljIć, "Crkvene prilike u srednjovjekovnoj Humskoj zemlji", u: Povijest hrvatskog Počitelja, str. 110. 
biskupa prelazila rijeku Neretvu. Područje Makarskoga primorja, od ušća Neretve do Vrulje, kao i cijela župa Rastok koja se kasnije prema Sivriću i Anđeliću dobrim dijelom poklapala sa župom Velika, pripadali su Splitskoj te jedno vrijeme, vrlo kratko od 1185. do 1192., Hvarskoj biskupiji. ${ }^{6}$ Ostaje nejasno čijoj su jurisdikciji pripadali prostori srednjovjekovne župe Večenike-Večerić koja je prema Anđeliću obuhvaćala prostor Brotnja, Blata te bliže okolice Mostara s Bijelim Poljem i Drežnicom. ${ }^{7}$ Ako se Porfirogenetov Mokriskik može identificirati s Mokrim kod Širokoga Brijega, onda bi i ovi krajevi sredinom 10. stoljeća bili pod vlašću (za)humskoga kneza Mihovila, a to bi vjerojatno značilo i pod jurisdikcijom stonskoga biskupa.

O stonskim biskupima i prilikama u Stonskoj biskupiji u 10., odnosno 11. pa i 12. stoljeću vrlo malo je poznato. Sredinom 12. stoljeća pojavljuju se stonski biskupi Šimun i Gabrijel. Biskupa Šimuna spominje mljetski opat Mavro Orbini kao onoga koji je s ostalim biskupima bio potvrđen kao sufragan dubrovačkoga nadbiskupa Andrije iz Lucce 1141.-1142., a biskupa Gabrijela susrećemo kao potpisnika Splitskoga sabora 1060. godine. ${ }^{8}$ Poslije Gabrijela prvi poznati biskup, možda i njegov nasljednik, bio je biskup Donat kojega je humski knez Miroslav (kao knez se u dokumentima spominje prvi put 1181.), brat raškoga velikog župana Stefana Nemanje, zavladavši Humskom zemljom početkom 80 -ih godina 12. stoljeća, protjerao iz njegove biskupije. Biskup je Donat ostao izgnanik do kraja života. Umro je na Lokrumu 1211. godine. ${ }^{9}$ Dok je biskup bio prognanik, čini se da je jurisdikciju na prostoru njegove biskupije preuzeo dubrovački nadbiskup. Na ovakav zaključak upućuje podatak

6 KARLO JURIŠIĆ, Katolička Crkva na biokovsko-neretvanskom području u doba turske vladavine, Zagreb, 1972., str. 9. O župi Velika: MariJan Sivrić - Tomislav ANĐELIĆ, "Srednjovjekovna župa Velika (Veljaci) u Humskoj zemlji", u: P. ANĐELIĆ - M. Sivrić - T. AnĐelić, Srednjovjekovne Humske župe, str. 119-133.

7 O župi Večenike-Večerić: PAvao AnĐElić, "Srednjovjekovna župa Večenike (Večerić) i postanak Mostara", u: P. AnĐelić - M. Sivrić - T. AnĐelić, Srednjovjekovne Humske župe, str. 161-182.

8 Mavro Orbini, Kraljevstvo Slavena, Snježana Huskić (prijevod), Franjo ŠaNJEK (ur.), Zagreb, 1999., str. 312; Velimir BlažEviĆ, Crkveni partikularni sabori i dijecezanske sinode na području Hrvatske i drugih južnoslavenskih zemalja, Zagreb, 2012., str. 74. Postoji bula pape Inocenta II. datirana 11. lipnja 1142. kojom papa potvrđuje dubrovačkom nadbiskupu Andriji metropolitanska prava nad Stonskom i Trebinjskom biskupijom ali u njoj se ne spominju, kao i obično, imena biskupa. Smičiklas smatra da je bula sumnjiva. Codex diplomaticus, II., str. 51-53.

9 Cronica Ragusina Junii Restii, Ab origine urbis usque ad annum 1451, Scriptores, II., u: Monumenta spectantia historiam Slavorum meridionalium, Speratus NoDILO (ur.), Zagreb, 1893., str. 75. 
što ga donosi dubrovački kroničar Ragnina koji piše da je dubrovački nadbiskup Bernard na putu prema Bosni u Zahumlju pete godine svoga nadbiskupovanja, dakle 1194., blagoslovio crkvu na čast sv. Kuzme i Damjana te činjenica da i sam papa prilikom imenovanja nadbiskupa Bernarda 1189. i njega samoga preporučuje Nemanji i braći tražeći od njih da ga prihvate i poštuju u svemu što je Božje. ${ }^{10}$

\subsection{Jezik i obred u bogoslužju}

Ono što se može razabrati iz povijesnih izvora prevladavajući bogoslužni jezik na području Stonske biskupije bio je slavenski. Neposredno prije zasjedanja Splitskoga sabora 925. godine, na kojem su bili prisutni i stonski i dubrovački biskup kao i Mihovil "knez Humljana", papa Ivan X. (914.-928.) pisao je splitskome nadbiskupu Ivanu i njegovim sufraganima da je čuo da se na području njihovih biskupija "širi druga nauka, koja se ne nalazi u svetim knjigama" precizirajući poslije da je riječ o Metodovu nauku i pozvao ih je da se potrude "da se u zemlji Slavena obavlja služba Božja prema običajima svete rimske Crkve, tj. na latinskom, a ne na drugom jeziku". ${ }^{11}$ Tri godine poslije jedan od zaključaka također Splitskoga sabora iz 928. koji je potvrdio papa Leon VI. (928.) izričito je upozorio biskupe Stona, Dubrovnika i Kotora da "u svojim sjedištima i granicama u svemu slijede istinu kršćanske vjere". Premda zaključak sabora 928. izričito ne spominje slavensko bogoslužje ni "Metodov nauk", iz konteksta papinskih pisama u vrijeme održavanja Splitskih sabora moglo bi se zaključiti da se upravo radilo o njemu. ${ }^{12}$

10 "Costui (nadbiskup Bernard, op. MK.), alle preghiere di Jurcha, zupano di Rascia, andò in la provincia de Zachulmia, l'anno quinto del suo officio, e ivi consacrò la ecclesia di santi Cosmo i Damiano." Annales Ragusini Anonymi item Nicolai de Ragnina, Scriptores, I., u: Monumenta spectantia historiam Slavorum meridionalium Speratus Nodilo (ur.), Zagreb, 1883., str. 219. Crkva posvećena sv. Kuzmi i Damjanu mogla bi se nalaziti u selu Vrači kod Blagaja. Odatle potječe kameni natpis pronađen na jednom grobu u Blagaju koji govori o gradnji neke crkve u vrijeme Nemanje. Marko Vego, "Novi i revidirani natpisi iz Hercegovine", u: Glasnik Zemaljskog muzeja, 15-16, Arheologija, n. s., Sarajevo, 1960.-1961., str. 265-266. Preporuka nadbiskupa Bernarda Nemanji i braći. Codex diplomaticus, II., str. 238. O tome također: Konstantin JiRečen, Istorija Srba, Politička historija do 1537. godine, (ćir.), Jovan Radonić (preveo), Beograd, 2006., (fototipsko izdanje), str. 158; I. Puljić, "Crkvene prilike u srednjovjekovnoj Humskoj Zemlji", str. 120-121.

11 Latinski tekst pisma: Codex diplomaticus, I., str. 30. Hrvatski prijevod: Izvori za hrvatsku povijest, I., (do god. 1107.), NADA KLAIĆ (ur.), Zagreb, 1955., str. 32-33.

12 Zaključci sabora iz 928. Codex diplomaticus, I., str. 27-28; Neven Budak, "Prilog valorizaciji Humsko-dukljanskog kulturnog područja u prvim fazama njegova razvitka (do 12. stoljeća)", u: Starohrvatska prosvjeta, 16, Zagreb, 1986., str. 126. 
Dubrovački kroničari donose podatak da je bosanskoga biskupa Radogosta, najvjerojatnije 1195., u Dubrovniku zaredio nadbiskup Bernard te da je Radogost, ne znajući ni jedan drugi jezik osim "slavenskog", zakletvu vjernosti i poslušnosti svome metropoliti položio na "slavenskom" jeziku "koji je po starom privilegiju uživao ovu pogodnost, dobivenu od pape Ivana VIII. 880. godine". ${ }^{13}$ Činjenica da su Dubrovčani poznavali privilegij koji je papa Ivan VIII. dao slavenskom jeziku govori u prilog da je služba Božja na slavenskome jeziku na dubrovačkom jurisdikcijskom području u ranom srednjem vijeku bila dobrano poznata. ${ }^{14}$ Još sigurniji dokaz postojanja slavenske službe Božje na dubrovačkome jurisdikcijskom području u to doba govori činjenica da je ona postojala i u kasnome srednjem vijeku. Češki kroničar Pulkava 1374. piše da se "po nadbiskupijama, i pokrajinama splitskoj, dubrovačkoj i zadarskoj i kod svih njihovih podružnih biskupa, i po mnogim drugim biskupijama, tako biskupi kao i svećenici mise i druge bogoštovne čine služe do danas na slavenskom jeziku". ${ }^{15}$ Dubrovački arhivski spisi s kraja 14. stoljeća donose velik broj podataka o slavenskim svećenicima, odnosno svećenicima koji su se na starom dubrovačkom području, bez Pelješca, Primorja i Konavala, služili slavenskim jezikom u liturgiji. Iz podataka koje je prikupio i objavio A. Liepopili slavenskim jezikom u liturgiji se služilo u Gružu, Župi, Zatonu, Rijeci i Šumetu. ${ }^{16}$ Ako se u ovim mjestima krajem 14. stoljeća koristio slavenski jezik u bogoslužju, nemamo razloga sumnjati da nije korišten i u stoljećima prije toga te ako je korišten takoreći u predgrađu "latinskog" Dubrovnika, nema sumnje da je korišten također i u njegovim sufraganskim biskupijama jer su puno više od "predgrađa" bile naseljene slavenskim stanovništvom. ${ }^{17}$ Što se pitanja obreda tiče, čini se da je na ovim rubnim prostorima dolazilo do miješanja zapadnoga i istočnoga. U prilog ovoj tezi idu istraživanja Ki-

13 "Nè sapendo (biskup Radogost, M.K.) le lettere latine, nè altre, eccetto le slavoniche, quando fece il giuramento della fedeltà ed obedienza al suo metropolitano, lo fece in lingua slava, la quale per antico privilegio gode questo beneficio, avuto dal pontefice Giovanni VIII, nell'anno 880." Cronica Ragusina Junii Restii, str. 63.

14 Pismo Industriae tuae pape Ivana VIII. moravskom knezu Svatopluku u hrvatskome prijevodu pogledati u: Franjo ŠAnJeK, Crkva i kršćanstvo u Hrvata, 1., Srednji vijek, Zagreb, 1988., str. 100-101.

15 Ante Liepopili, "Slavensko bogoslužje u Dubrovniku", u: Rad Jugoslavenske akademije znanosti i umjetnosti, knjiga 220, Zagreb, 1919., str. 41; DomINIK MaNDIĆ, Državna i vjerska pripadnost sredovječne Bosne i Hercegovine, Mostar, ${ }^{32} 2013$., str. 371.

16 A. Liepopili, "Slavensko bogoslužje u Dubrovniku", str. 43-51.

17 O naseljenosti dubrovačkoga područja "izvan zidina" slavenskim stanovništvom u 13. stoljeću pogledati: Josıp Lučić, "Etnički odnosi na dubrovačkom teritoriju u XIII. stoljeću", u: Jugoslovenski istorijski časopis, 4, Beograd, 1969., str. 28-31. 
jevskih [Ki] i Sinajskih [Si] listića koja je obavila Marija Pantelić. Radi se o najstarijim dosad pronađenim fragmentima staroslavenske liturgije. Analizirajući spomenute listiće došla je do zaključka da se u njima prožimaju zapadna i istočna liturgija te da su korišteni i dijelom nastali od kraja 10. do početka 12. stoljeća na južnohrvatskom prostoru, odnosno na području dubrovačke crkvene jurisdikcije. ${ }^{18}$ Nakon analize Pantelić je zaključila: "Ki predstavljaju najstariji liturgijski spomenik jednog dijela najstarijega Gregorijanskog sakramentara s istočnim leksikom i izrazima, a $S i$ najstariju istočnu liturgiju protkanu oracijama suvremene zapadne duhovnosti. Mlađi spisi $\mathrm{Ki}_{2}, \mathrm{Si}_{2},{ }_{3}$ iz konca 11. ili početka 12. st. svjedoče upotrebu $K i$ i Si na pograničnom u to vrijeme, mješovitom području kao što je bila dubrovačka Astarea i poluotok Pelješac sa svojim humskim zaleđem."19 Do sličnih spoznaja došao je ugledni paleoslavist i jedan od najkompetentnijih istraživača staroslavenskih evanđelja Josip Vrana proučavajući Miroslavljevo evanđelje. Prema Vrani evanđelistar posvećen humskom knezu Miroslavu pisan je za uporabu u liturgiji istočnoga obreda, međutim, njegovi pisari, osobito prvi i treći, svoje su vještine naučili u zapadnome benediktinskom kulturnom krugu. Kako evanđelja zapisana u evanđelistaru već tada nisu bila upotrebljiva $\mathrm{u}$ istočnoj liturgiji i kako u njih nisu ušli reformatorski elementi istočne Crkve onoga vremena, zaključuje da je nastalo na području na kojem je jurisdikciju imala zapadna Crkva. Spominjanje humskoga kneza Miroslava upućuje na njegov nastanak na području kneževe vlasti. Najvjerojatnije su njegovi pisci bili domaći monasi benediktinske mljetske opatije, školovani u talijanskim apulijskim samostanima. ${ }^{20} \mathrm{Na}$ koegzistenciju zapadnoga i istočnoga obreda upućuje također bula protupape Klementa III. o osnutku Barske nadbiskupije i metropolije iz 1089. godine. Protupapa je barskom nadbiskupu podvrgao biskupije "srpsku, bosansku i trebinjsku ... i sve samostane kako Dalmatinaca, također i Grka i Slavena". ${ }^{21}$

18 Marija Pantelić, "O Kijevskim i Sinajskim listićima", u: Slovo, 35, Zagreb, 1985. str. 5-56. Sažetak, str. 53-54.

19 M. Pantelić, "O Kijevskim i Sinajskim listićima", str. 54.

20 Josip Vrana, "NIKOLA RODIĆ - GORDANA JOVANOVIĆ, 'Miroslavljevo jevanđelje. Kritičko izdanje. Srpska akademija nauka i umetnosti, Beograd, 1986., str. 344 i 3 priloga'", u: Slovo, 37, Zagreb, 1987., str. 195-201; Marija PAntelić, "JOSIP VRANA, L'Évangéliaire de Miroslav, Contribution à l'étude de son origine. Mouton et Co. 1961. 'S-Gravenhage. Str. 211+10 fotografija", u: Slovo, 14, Zagreb, 1964., str. 137-141.

21 "... et omnia monasteria tam Dalmatinorum quam Graecorum atque Sclauorum". Acta et diplomata res Albaniae mediae aetatis illustrantia, I., (annos 344-1343 tabulamque geographicam continens), collegerunt et digesserunt: $\mathrm{D}^{\mathrm{r}}$ Ludovicus de 


\section{Vjerske prilike u Humskoj zemlji od osnutka Srpske arhiepiskopi- je do 30 -ih godina 14 . stoljeća}

\subsection{Od osnutka Zahumske eparhije do obnove Stonske biskupije}

Crkvene prilike na prostoru Humske zemlje počele su se mijenjati početkom 20-ih godina 13. stoljeća osnutkom Srpske arhiepiskopije. Do njezina osnutka ne može se govoriti o prisutnosti pravoslavlja na ovim područjima. Premda su Nemanjići naginjali istočnoj Crkvi, oni još do ovoga vremena nisu bili načisto kojoj Crkvi pripadaju ili žele pripadati. Sin Stefana Nemanje, Stefan Prvovjenčani zatražio je 1217. i dobio od pape Honorija III. (1216.-1227.) kraljevsku krunu, a njegov brat Vukan Nemanjić, vladar Duklje i Trebinja, ostao je katolik do kraja života. Humski knez Petar, koji je zavladao Humskom zemljom početkom 90-ih godina 12. stoljeća, za kojega Orbini piše da nije bio Nemanjić, nego "rodom iz Huma",22 čak je, kako piše dubrovački kroničar Resti, dva puta nudio Dubrovniku da postavi stonskoga biskupa tražeći za to novčanu nadoknadu, na što Dubrovčani, prema pisanju istoga kroničara nisu pristali. ${ }^{23}$

Međutim, godine 1219. dogodio se jedan od presudnih događaja vjerske i crkvene povijesti južnoslavenskih prostora. Podrškom carigradskoga patrijarha Manojla, bizantskoga cara Teodora I. Laskarisa i srpskoga kralja brata mu Stefana Prvovjenčanog, Rastko Nemanjić, koji se krajem 12. stoljeća zamonašio i uzeo ime Sava, u prvoj polovici 1219. godine izdvojio je ispod vlasti ohridskoga arhiepiskopa srpsku eparhiju i utemeljio samostalnu srpsku arhiepiskopiju koja će kasnije, u vrijeme cara Dušana, postati patrijarhat. U organizaciji srpske crkve, koja se počela provoditi 1220. godine, među eparhijama koje su uspostavljene nalazila se i Humska eparhija. Za osnivanje eparhije u Humu arhiepiskop Sava imao je povoljne crkvene i političke okolnosti. Zahumska, odnosno stonska biskupska stolica, bila je već duže vremena prazna, a Hum je upravo

Thallóczy, $D^{\text {r. }}$ Constantinus Jireček et $D^{r .}$ Emilianus de Sufflay, Vindobonae, MCMXIII, str. 27. Hrvatski prijevod navedenoga dijela bule: EDUARD PERIčıć, "Crkveno-pravni odnosi Dubrovnika i Bara, odnosno Dubrovačke i Barske nadbiskupije", u: Tisuću godina Dubrovačke (nad)biskupije, Zbornik radova znanstvenoga skupa u povodu tisuću godina uspostave dubrovačke (nad)biskupije / metropolije (998.-1998.), Dubrovnik, 2001., str. 344.

22 M. Orbini, Kraljevstvo Slavena, str. 313. Orbinijevo mišljenje prihvaćaju Jireček i Ančić. K. JirečEK, Istorija Srba, I., str. 171; M. ANČIć, Na rubu Zapada, str. 151-152.

23 Cronica Ragusina Junii Restii, str. 66, 75. 
te godine došao pod vlast njegova brata Stefana Prvovjenčanoga koji je protjerao domaćega kneza Petra. ${ }^{24} \mathrm{O}$ boravku humskoga episkopa u Stonu povijesni su izvori vrlo šturi. Jedini sigurni spomen njegova boravka u Stonu susrećemo 1239. godine i to kao sudionika na jednom "stanku" koji je trebao razriješiti neka prijeporna pitanja između Dubrovčana i Omišana. Uz Dubrovčane i Omišane "stanku" je prisustvovao episkop Ilarije i izaslanici srpskoga kralja Vladislava koji je tih godina vladao Humskom zemljom. ${ }^{25}$ Darovnica kralja Uroša I. iz 1243.-1253. govori o "svetoi crk'vi, domu Svetie Bogorodice u Stonu". Spominjanje crkve i doma upućuje na episkopsko sjedište te je episkop vjerojatno boravio u spomenutom domu uz crkvu sv. Marije od Lužina gdje je prije toga bilo sjedište katoličkoga biskupa. ${ }^{26}$ Međutim, njegov boravak u Stonu nije bio duga vijeka. Već se zasigurno zna da je episkop između 1253. i 1263. u manastiru sv. Petra na Limu što potvrđuje povelja kralja Uroša I. izdana tih godina. ${ }^{27}$ Zbog čega je i kada napustio Ston, izvori ništa ne govore, što je dalo povoda različitim domišljanjima. Srpski se povjesničari uglavnom drže Ćorovićeva mišljenja da se to dogodilo između 1252. i 1254. i kao razloge navode potres koji se dogodio u Stonu 1252. i prelazak župana Radoslava na stranu ugarsko-hrvatskoga kralja. ${ }^{28}$ Isto prihvaća i Dračevac bez ikakva kritičkog osvrta. ${ }^{29}$ Čini se da su Ćoro-

24 M. Ančić, Na rubu Zapada, str. 152.

25 Codex diplomaticus, IV., str. 77. Zanimljivo da Resti piše kako je Ilarion bio jedan od Omišana: "L'anno seguente poi, alli 9 di maggio, si congregò lo stanco nel luogo solito, in cui intervennero (...), e dalla parte degli Almisiani: Ilario vescovo, conte Nicolò di Vladimir ed il conte Pribislavo di Maldusio." Cronica Ragusina Junii Restii, str. 86. Također treba primijetiti, što će možda koristiti u nekim kasnijim istraživanjima, podudarnost imena biskupa Ilariona s cavtatskim svecem.

26 S dotadašnjom literaturom: MARIJA JANković, Episkopije i mitropolije Srpske crkve u srednjem veku, (ćir.), Beograd, 1985., str. 32; Ante Dračevac, "Ponovno osnivanje katoličke biskupije u Stonu", u: Zbornik radova u čast 650. obljetnice planske izgradnje Stona i Malog Stona, Ston, 1987., str. 82.

27 M. Janković, Episkopije i mitropolije Srpske crkve u srednjem veku, str. 107.

28 Vladimir Ćorović, "Značaj Humske eparhije", (ćir.), u: Srpski manastiri u Hercegovini, Beograd, 1999., str. 51-53; M. JAnković, Episkopije i mitropolije Srpske crkve u srednjem veku, str. 38; BoRIs NiLEvić, Srpska pravoslavna Crkva u Bosni i Hercegovini do obnove Pećke patrijaršije 1557. godine, (ćir.), Sarajevo, 1990., str. 32. Slijepčević je donio razna mišljenja koja su postojala u dotadašnjoj literaturi te zaključio: "Biće verovatno najtačnije, da je prenos sedišta humske episkopije izvršio episkop Danilo." Đoкo SLIJEPČEvić, "Humsko-hercegovačka eparhija i episkopi (mitropoliti) od 1219. do kraja XIX. veka", (ćir.), u: Episkopija Zahumsko-hercegovačka, Beograd, 2006., str. 121-127. Citirani tekst. str. 126. Episkop Danilo je živio u vrijeme kralja Milutina.

29 A. Dračevac, "Ponovno osnivanje katoličke biskupije u Stonu", str. 82-83. 
vićevi argumenti neodrživi. Potres kao razlog premještanja sjedišta jedne tako važne crkvene institucije teško se može prihvatiti. Zbog potresa je episkop mogao privremeno premjestiti svoje sjedište ali ne za stalno kako je riječ u ovom slučaju. Mišljenje da bi episkopa na premještanje sjedišta mogao potaknuti prelazak župana Radoslava na stranu ugarsko-hrvatskoga kralja također je neodrživo jer je već Radoslavov otac knez Andrija prešao na stranu kralja istoga kraljevstva kada je morao bježati pred svojim rođakom srpskim kraljem Vladislavom iz Huma, svakako prije lipnja 1237., i skloniti se, negdje blizu Splita, na područje ugarsko-hrvatskoga kralja. ${ }^{30}$ Ono što je moglo natjerati episkopa da premjesti sjedište svoje eparhije mogle su biti nepovoljne političke prilike, kako je i Ćorović predmnijevao ali ih je smjestio desetljeće kasnije. Stoga, uvjerljivije izgleda Ančićevo mišljenje, koje je i Puljić naznačio, da se episkop povukao na Lim nakon tatarske provale 1242. koja je opustošila Humsku zemlju i s njom povezan povratak na vlast humskoga kneza Andrije koji nije bio u dobrim odnosima sa srpskim kraljevima kao zaštitnicima nacionalne Crkve. ${ }^{31} \mathrm{O}$ prisilnom odlasku episkopa pisao je stonsko-korčulanski biskup Ivan sedamdesetih godina 14. stoljeća. U pismu upućenom trebinjskom biskupu papa Urban IV. (1378.-1389.) 1378. godine piše da je spomenuti biskup Ivan pisao njegovu predšasniku papi Grguru XI. (1370.-1378.) da su stanovnici Stona i Stonske biskupije, "koji su od davnih vremena unatrag bili raskolnici i nevjernici" iz grada i biskupije istjerali "nekog sina bezakonja, koji je već dugo po obredu Grka i raskolnika držao zauzetima episkopat i crkvu Stonsku". ${ }^{32}$

Na osnovi raspoložive izvorne građe teško je zaključiti kakve je poremećaje na vjerskom, odnosno crkvenom polju izazvalo osnivanje Humske

30 M. AnčIć, Na rubu Zapada, str. 153.

31 M. Ančić, Na rubu Zapada, str. 153-154, 157-158. Puljić je 1996. naznačio da bi razlog premještanja mogao biti što srpska vlast u Humu "nije bila ni jaka ni stabilna, a i relativno kratka" te je tomu mogla također doprinijeti provala Tatara. On također dopušta mogućnost potresa ali kao najvažniji razlog navodi "što se pučanstvo lako ne povodi za politički nametnutom religijom koju prihvaćaju uglavnom pojedinci iz koristoljublja". I. PulJIĆ, "Crkvene prilike u srednjovjekovnoj Humskoj zemlji", str. 124.

32 "Dudum siquidem pro parte venerabilis fratris nostri Joannis, episcopi Stagnensis, exposito felicis recordationis Gregorio pape XI. predecessori nostro, quod dilecti filii ciues et incole et habitatores ciuitatis et diocesis Stagnensis, qui a longinquis retro temporibus scismatici et infideles fuerant, ueram et catholicam fidem agnoscentes ad ecclesie unitatem erant reuersi, quodque dicti ciues, incole et habitatores quendam iniquitatis filium, qui secundum ritum Grecorum et scismaticorum episcopatum et ecclesiam Stagnensem iam diu detinuerat occupatos, de ciuitate et diocesi predictis expulerant ...". Urban VI. trebinjskom biskupu 24. studenoga 1378., Codex diplomaticus, XVI., str. 415. 
eparhije. Čini se da u početku nije bilo zamjetnijih poremećaja. Gledano "odozdo" očima vjernika pa vjerojatno i svećenika koji su, kao što je već spomenuto, slavili obrede na slavenskom jeziku i vjerojatno s mješavinom zapadnoga $i$ istočnoga obreda neka znatnija promjena nije se mogla primijetiti. ${ }^{33}$ Možda im je čak Ilarion bio razumljiviji od Donata. Zanimljivo je primijetiti činjenicu da iz toga vremena nije poznata nikakva negativna reakcija na ovaj, današnjim očima gledano, uzurpatorski čin, niti crkvenoga niti političkoga Dubrovnika. ${ }^{34}$ Da ni za srpskoga kralja Stefana Prvovjenčanoga to nije predstavljalo nikakav lom u crkvenim odnosima, govore dvije činjenice. U ožujku 1220. kralj je pisao papi Honoriju III. (1216.-1227.) kao sin rimske Crkve moleći ga da Božji i njegov blagoslov budu uvijek nad njegovom krunom i zemljom. ${ }^{35}$ Nekoliko godina poslije osnutka Humske eparhije, koju je prema povelji

33 O tome također J. Šidak u radu "Vjerski odnosi u Stonu i na Stonskom ratu (Pelješcu) u srednjem vijeku" samo što njegovu tezu da je slavensko bogoslužje koje je prema njemu bilo "najvjerojatnije na istočnom obredu" produžilo "da nesmetano živi i čak je moglo spokojnije živjeti, bez bojazni pred univerzalističkim težnjama katolicizma" valja smatrati neodrživom. JarosLaV ŠIDAK, "Vjerski odnosi u Stonu i na Stonskom ratu (Pelješcu) u srednjem vijeku", u: Historijski zbornik, XXXIII.-XXXIV. (1), Zagreb, 1980.-1981., str. 279. Ponajprije, Šidak za to ne donosi nikakav argument nego piše "najvjerojatnije". Drugo, zato što istočni obred nije bio prevladavajući nego zapadni jer su do toga vremena Ston i Humska zemlja u crkvenom pogledu redovito bili okrenuti prema zapadu. Treće, zbog blizine istoka i bizantske pa djelom i bugarske vlasti vjerojatno je zapadni obred bio prihvatio neke dijelove istočnoga obreda ali ne u toj mjeri da je istočni postao prevladavajući. Četvrto, što se tiče teze da je osnutkom Humske eparhije slavensko bogoslužje moglo "spokojnije živjeti, bez bojazni pred univerzalističkim težnjama katolicizma", valja imati u vidu da je takva misao konstrukt kasnijih vremena koju autor primjenjuje ondje gdje joj nije mjesto jer je slavensko bogoslužje živjelo i nekoliko stoljeća poslije na istom prostoru u okviru "univerzalnog katolicizma". ANTE LIEPOPILI, "Slavensko bogoslužje u Dubrovniku", str. 30-58. Mihajlo Dinić, "Slovenska služba na teritoriju Dubrovačke Republike u srednjem vijeku", (ćir.), u: Prilozi za književnost, jezik, istoriju i folklor, 14, 1-2, Beograd, 1934., str. 50-56. Minajlo Dinić, "Chiuriliza slovenskih popova dubrovačke građe", (ćir.), u: Prilozi za književnost, jezik, istoriju i folklor, 26, 3-4, Beograd, 1960., str. 274-279.

$34 \mathrm{Kad}$ su Dubrovčani sastavljali zapis o stanku u Stonu na kojem je sudjelovao i episkop Ilarion, uopće nisu osjetili potrebu dodati mu uza sakramentalni naslov i neki pridjev poput srpski ili raskolnički. Zapisnik o stanku u Stonu 1239. godine. Codex diplomaticus, IV., str. 77.

35 "Quemadmodum omnes Christiani diligunt vos et honorant, et pro Patre et Domino retinent, ita et nos desideramus Sanctae Romanae Ecclesiae, et Vestre Paternitatis filium nominari, affectans quod benedictio et confirmatio Dei et vestra sit, si verbis placet, super coronam et terram nostram semper manifeste." DANIELE FARlato - JACOBo Coleto, Illyrici sacri, VII., Venetiis, MDCCCXV., str. 34. (dalje: Illyrici sacri); K. JIRIČEK, Istorija Srba, I., str. 169. 
Uroša I. kralj Stefan obdario posjedima u Stonu i Humskoj zemlji, kralj je također između 1222. i 1228. godine obdario i mljetske benediktince, potvrdivši im posjed cijeloga otoka Mljeta i poklonivši im na Râtu (Pelješcu) crkvu sv. Stjepana i Jurja u Janjini, zemlje na području Janjine i Popove Luke, tj. prostor od Motoružnice do Žuljane od jednoga mora do drugoga te crkvu sv. Nikole u Stonu. ${ }^{36}$ Humsku eparhiju, odnosno crkvu svete Bogorodice, kralj je Stefan obdario u Stonu zemljom oko crkve, te na Râtu polovicom zemlje u Crnoj gori. ${ }^{37}$ Iz darovnicâ, koje su nastale $\mathrm{u}$ nekoliko godina razlike ali tako da je prije nastala ona crkvi sv. Bogorodice, proizlazi da su u Stonu u jednoj crkvi liturgiju slavili humski episkop i njegovi monasi, a u drugoj, u neposrednoj blizini, mljetski benediktinci. Do kada je to potrajalo, ne znamo. Darovnicu Stefana Prvovjenčanoga mljetskim benediktincima potvrdio je gotovo stoljeće kasnije srpski kralj Milutin te papa Ivan XXII. (1316.-1334.) godine 1324. i 1325., doduše bez izričita spomena crkve sv. Nikole. ${ }^{38}$ Kako je bilo u unutrašnjosti Humske zemlje, izvori ništa ne govore. Natpis iz Vidoštaka kod Stoca, koji je Vego datirao u 1231. godinu o popu Dabiživu i "divici Mariji" koja je bila njegovo "podružije - žena" sam po sebi ne govori ništa o njegovoj crkvenoj pripadnosti. ${ }^{39}$ Celibat kao argument različitosti za to vrijeme ne može se koristiti. Četvrti lateranski sabor samo je petnaestak godina prije, 1215. godine, donio odluku u kanonu koji govori O kažnjivoj neuzdržljivosti klerika da svećenici "koji se prema običaju svoje zemlje nisu odrekli ženidbene veze, ako su bili pali, neka se teže kazne, jer se mogu služiti zakonitom ženidbom". ${ }^{40} \mathrm{Na}$ lokalitetu

36 Darovnica objavljena u: Monumenta serbica spectantia historiam Serbiae Bosnae Ragusii, Fr. Miklosich, (edidit), Graz, 1964., str. 8-10. Codex diplomaticus, III., str. 223-225. Usporedi također: A. DračEvac, "Ponovno osnivanje katoličke biskupije u Stonu", str. 83; Dijana Korać, Vjera u Humskoj zemlji, Mostar, 2008., str. 26; Božo BaničEvić, "Osnivanje Korčulanske biskupije", u: Tisuću godina Dubrovačke (nad)biskupije, str. 222.

37 Povelja kralja Uroša I. iz 1243.-1253. crkvi sv. Bogorodice u Stonu u: Zakonski spomenici srpskih država srednjega veka, prikupio i uredio STOJAN NovaKović, Beograd, 1912., str. 600-601; M. JAnKović, Episkopije i mitropolije Srpske crkve u srednjem veku, str. 102-103.

38 Milutinova darovnica: Monumenta serbica, str. 71; Codex diplomaticus, VI., str. 156. Papine potvrde: Codex diplomaticus, IX., str. 197-198, 245.

39 O natpisu: Marko Vego, Zbornik srednjovjekovnih natpisa Bosne i Hercegovine, Sarajevo, 1964., str. 10-11; Isti, Iz historije srednjovjekovne Bosne i Hercegovine, Sarajevo, 1980., str. 176-178. Novijeg datuma: MARINKA Šimić, "Pismenost u srednjovjekovnoj Hercegovini", u: Hum i Hercegovina kroz povijest, I., str. 539-540.

40 Kanon 14. De incontinentia clericorum punienda: "Qui autem secundum regionis suae morem non abdicarunt copulam conjugalem, si lapsi fuerint, gravius puni- 
Podvornice u Lištanima kod Livna, na području Splitske nadbiskupije, pronađen je nadgrobni natpis pisan crkvenoslavenskim jezikom koji je, kako se pretpostavlja, nastao tijekom 12. stoljeća a govori o popu Tjehodragu i njegovih pet umorenih sinova. ${ }^{41}$ Ono što se zasigurno može zaključiti iz natpisa s Vidoštaka jest da je pop Dabiživa pripadao svećenstvu crkvenoslavenske tradicije i vjerojatno je, ako je Vidoštak u to vrijeme pripadao jurisdikciji humskoga episkopa, priznavao njegovu nadležnost.

Osim posjeda oko crkve sv. Bogorodice u Stonu i polovice zemlje u Crnoj gori Stefan Prvovjenčani spomenutu je crkvu, odnosno eparhiju obdario još i selom Bivoljim Brdom s Poljicom i zaseocima Topolnicom i Morugom, selom Brštanikom s vinogradima, selom Živogošćem te selima Trnova i Osojnik u Primorju. ${ }^{42}$ Osim ovih starih posjeda, kralj Uroš I. obdario je crkvu sv. Bogorodice u Stonu na području Humske zemlje još cijelom "knežinom"43 i polovicom luga u Stonu, te selom Ponikve sa zaseokom Duba i nekom zemljom kod Žuljana. ${ }^{44}$ Svojom drugom poveljom, koja je nastala između 1254. i 1263., kralj Uroš I. povećao je posjede Humske eparhije darovavši joj u Stonu knežev vrt i "vjerojatno" cijeli lug, te dva vinograda, jedan uz crkvu sv. Petra, a drugi u Vinom. U Primorju je eparhija dobila zaselak Ustrn ${ }^{45}$ kod Živogošća, selo Malikovo ${ }^{46}$ te u Sirakovićima tri dijela zemlje s vinogradima i ljudima - "Konjuhov, Kovačev i Vratkov" dio. ${ }^{47}$

antur, cum legitimo matrimonio possint uti." JoAnnes Dominicus Mansi, Sacrorum conciliorum nova et amplissima collectio, vol. 22, Graz, 1961., str. 1003.

41 M. Šimić, "Pismenost u srednjovjekovnoj Hercegovini", str. 538.

42 Povelja kralja Uroša I. iz 1243.-1253. crkvi sv. Bogorodice u Stonu u: Zakonski spomenici srpskih država srednjega veka, str. 600-601; M. JANKović, Episkopije $i$ mitropolije Srpske crkve u srednjem veku, str. 102-103. Uz ove posjede u povelji Uroša I. stoji "kak si e od predi bilo" na temelju čega se zaključuje da su to bili prvotni posjedi stonske Bogorodičine crkve.

43 Pod pojmom "knežina" vjerojatno bi trebalo razumjeti vlastelinsku rezervu koju su obrađivali seljaci ovisni o svome gospodaru. Miloš Blagojević, Zemljoradnja u srednjovjekovnoj Srbiji, Beograd, 1973., str. 357, citirano prema: M. JANKović, Episkopije i mitropolije Srpske crkve u srednjem veku, str. 106, bilj. 20.

44 M. Janković, Episkopije i mitropolije Srpske crkve u srednjem veku, str. 105-106. U ovoj je povelji uočljivo povećanje vlastelinstva i veća koncentracija naselja oko manastira sv. Petra na Limu. Isto, str. 107.

45 Danas naselje Strnj - dio Živogošća.

46 Danas Majkovi kod Slanog.

47 M. Janković, Episkopije i mitropolije Srpske crkve u srednjem veku, str. 108. 
Kada je Uroš I. obdarivao eparhiju ovim posjedima, Humskim je kneštvom vladao knez Andrija a njegovim zapadnim dijelom kao župan njegov sin Radoslav koji je 1254. stupio u savez s Dubrovčanima i Bugarima protiv kralja Uroša. Darivanje posjeda s jedne strane i stupanje u savez sina, koji za sebe kaže da je "vjer'n' klet'venik' gospodinu kralu ugarskomu", a ne oca s druge strane, kako je primijetio Ančić, oslikava ondašnji položaj humskoga kneza koji se nalazio na razmeđu utjecaja ugarsko-hrvatskoga i srpskoga kralja i morao računati na blizinu obojice posebno ovoga posljednjeg koji je Hum držao svojom djedovinom. Sve do prvih godina 14. stoljeća srpski su kraljevi imali neke prihode iz Huma kao i humski episkopi ${ }^{48}$ Posljednjih desetljeća 13. stoljeća Humsko je kneštvo bez pravoga gospodara. Andrijin sin Juraj spominje se kao gospodar Drijeva 1280. godine.$^{49}$ Nasljednici Andrijina sina Bogdana vladali su Popovom. ${ }^{50}$

\subsection{Vrijeme obnovljene Stonske biskupije}

U vrijeme kada je Humska zemlja bila bez pravoga gospodara dolazi do imenovanja stonskoga biskupa. Najprije je papa Martin IV. (1281.-1285.) pisao dubrovačkomu nadbiskupu 13. lipnja 1284. da je do njega došla vijest da su trebinjska i stonska katedralna crkva već dugo vremena prazne te mu naređuje, "ako je i njemu to isto poznato", da imenuje trojicu ili dvojicu biskupa.$^{51}$ Kako je papa Martin umro prije nego što je dubrovački nadbiskup primio njegovo pismo, nadbiskup se obratio njegovu nasljedniku papi Honoriju VI. (1285.-1287.) s upitom može li postupiti po naredbi njegova predšasnika na što mu je papa Honorije pozitivno odgovorio. ${ }^{52}$ Nedugo nakon ovoga drugog pisma pojavljuje se stonski biskup Petar koji osim stonskoga nosi i naziv korčulanski. Biskup Petar Stamnensis godine 1287. zajedno s dubrovačkim nadbiskupom Bona-

48 M. Ančić, Na rubu Zapada, str. 155-157.

49 Đuro Tošıć, Trg Drijeva u srednjem vijeku, (ćir.), Sarajevo, 1987., str. 44.

50 D. Mandić, Državna i vjerska pripadnost sredovječne Bosne i Hercegovine, str. 269.

51 Papino pismo: Codex diplomaticus, VI., str. 488-489.

52 Papino pismo: Codex diplomaticus, III., str. 142-143, krivo datirano 1216. godine. To je navelo neke povjesničare da govore o imenovanju stonskoga biskupa 1216. godine. A. Dračevac, "Ponovno osnivanje katoličke biskupije u Stonu", str. 8182; V. Ćorović, "Značaj Humske eparhije", str. 46. Na to upozoreno u: I. PuljIć, "Crkvene prilike u srednjovjekovnoj Humskoj zemlji", str. 128-129. Dokument se nalazi ispravno datiran u: Codex diplomaticus, VI., str. 551. Također u: Vetera monumenta Slavorum meridionalium historiam illustrantia, I., (ab Innocentio pp. III. usque ad Paulum III. 1198-1549.), ab Augustino Theiner, Romae, 1863., str. 103. Oba su pisma također objavljena u: Illyrici sacri, VI., str. 293. 
venturom, barskim nadbiskupom Mihovilom i još nekim drugim biskupima boravio je u Narniju u Italiji (Umbrija), gdje su obdarili crkvu sv. Juvenala i zadobili predviđene oproste. ${ }^{53}$ Biskup se Petar također spominje u dubrovačkim izvorima 1297. godine. Te mu je godine, 11 . veljače, Marin Kružić, sin pokojnoga Junija Kružića, posudio 85 perpera koje mu je trebao vratiti do početka sljedeće korizme..$^{54}$ Godinu dana prije, 1296., neki su ljudi stonskoga biskupa u selu Trnova opljačkali Dobroslava Dragušića sa Šipana uzevši mu kravu s junetom. ${ }^{55}$ Ćorović, Slijepčević i Janković bez pridržaja govore da se ovdje radilo o ljudima humskoga episkopa srpske arhiepiskopije. ${ }^{56} \mathrm{~S}$ njihovim se mišljenjem teško složiti. Povijesna događanja, činjenice i izvori upućuju na to da se radi o stonskom biskupu Petru. Za to ima više razloga:

1 - Ponajprije naslov "stonski biskup" za humskoga episkopa nije zabilježen nigdje ni u srpskim ni u dubrovačkim izvorima. Teško da bi Dubrovčani stonskim nazivali onoga koji ne stoluje u Stonu. Osim toga, ni službeni naziv njegove eparhije nije stonska nego humska.

2 - Za razliku od humskoga episkopa koji je na Limu, stonsko-katolički biskup Petar tu je, u njihovoj blizini. Štoviše, dubrovački izvori nazivaju Petra izričito stonskim biskupom, što se nigdje ne susreće za humskoga episkopa. I Petrovi predšasnici a i nasljednici redovito se nazivaju stonskim biskupima, što je tradicija zapadne Crkve. Već na saboru u Splitu 928. godine spominje se stonski biskup. Biskup se Gabrijel spominje kao stonski 1044. godine kada potvrđuje lokrumskom samostanu posjede crkve sv. Pankracija na Lokrumu. ${ }^{57}$ Pape Martin IV.

53 Illyrici sacri, VI., str. 328; I. PulJIĆ, "Crkvene prilike u srednjovjekovnoj Humskoj zemlji", str. 129, osobito bilj. 165.

54 "Die XI februari (1279). C. Marinus quondam Junii Crosii promisit et obligauit se dare et solvere domino Petro episcopo Stagniensi et curculensi yperperos LXXXV usque ad proximum festum carnispriuium sine aliquo inducio et questione aliqua." Spisi dubrovačke kancelarije, knjiga 3, Zapisi notara Tomazina de Savere 1284-1286 - Diversa cancelllariae II (1284-1286), Zapisi notara Aca de Titullo 1295-1297 - Diversa cancellariae III (1295-1297), prepisao i pripremio JosIP Lučić, Zagreb, 1988., str. 332.

55 "Die XVIIII septembirs (1296). C. Dobrosclavus Dragusich de Jupana suo sacramento conqueritur quod die jouis preterito, in contrata Ternoue, Rastenus et Craislauus et socii homines episcopi Stagni acceperunt ei unam vacam cum uno mançolo." Spisi dubrovačke kancelarije, knjiga 3, str. 290.

56 V. ĆORović, "Značaj Humske eparhije", str. 51; Đ. SLIJePČEvić, "Humsko-hercegovačka eparhija i episkopi (mitropoliti) od 1219. do kraja XIX. veka", str. 126; M. JANKOVIĆ, Episkopije i mitropolije Srpske crkve u srednjem veku, str. 110.

57 Illyrici sacri, VI., str. 325-326. 
i Honorije VI. pišu dubrovačkom nadbiskupu da su trebinjska i stonska katedralna crkva prazne. ${ }^{58}$

3 - Humski episkop već je više od pola stoljeća na Limu i od one 1239. godine nema mu nikakva spomena nigdje na području Humske zemlje ni u zaleđu Dubrovnika.

4 - Između Humske zemlje i Lima nalazi se Trebinjska biskupija, čiji je biskup Salvije (Slav) protjeran i lišen dobara tek oko 1250. godine. ${ }^{59}$

$\mathrm{Na}$ temelju iznesenoga, ne bi trebalo biti teško prihvatiti zaključak da se ovdje radilo o stonskom katoličkom biskupu Petru. Spominjanje sela Trnove u posjedu stonskoga biskupa, sela koje je inače prije bilo u posjedu humskoga episkopa, odnosno Bogorodičine crkve u Stonu, govori da je već tada humski episkop izgubio neke posjede, možda i sve u Humskoj zemlji, na što će se žaliti episkop Danilo kralju Milutinu početkom 14. stoljeća. ${ }^{60}$ Po logici stvari biskup je veoma lako mogao naslijediti episkopove posjede, a i svećenstvo i puk lako je moglo prihvatiti Petra kao što je nekada prihvatio "Ilariona" umjesto Donata. Na takav razvoj prilika upućuju i ondašnje političke prilike. Krajem 13. stoljeća Hum je, kao što je već napomenuto, bez gospodara. Trgom Drijeva i okolinom vlada sin kneza Andrije Juraj, a Popovom nasljednici njegova sina Bogdana. Susjedno Trebinje i Primorje u vlasti je kraljice majke Jelene koja je bila katolkinja i koja je po svoj prilici tražila od pape Martina IV. da se postave biskupi u Trebinju i Stonu. ${ }^{61}$ Okruženje koje je u svakom slučaju pogodovalo stonskomu biskupu.

Početkom 14. stoljeća Humom su ovladali Šubići koji su upravu nad zemljom povjerili svojim velikašima Nelipčićima. Kao knez, odnosno "gospodar" Humske zemlje 1303. i kasnije, pojavljuje se Konstantin

58 Isto, str. 293.

59 Codex diplomaticus, V., str. 342.

60 "ni vr'hovine ne ima, ni biri, niedinog dohod'ka niotkuder". Povelja kralja Milutina: Zakonski spomenici srpskih država srednjega veka, str. 597; M. JANKović, Episkopije i mitropolije Srpske crkve u srednjem veku, str. 40.

61 Konstantin Jireček, Istorija Srba, Kulturna historija, (ćir.), II., Jovan Radonjić (preveo i dopunio), Beograd, 2006., (fototipsko izdanje), str. 264; A. DraČEvaC, "Ponovno osnivanje katoličke biskupije u Stonu", str. 83; I. PuljIć, "Prva stoljeća Trebinjske biskupije", str. 68; Đ. Tošıć, Trebinjska oblast u srednjem vijeku, Beograd, 1998., str. 81; IviCA Puljić, "Sedam stoljeća otoka Mrkana u naslovu trebinjskih biskupa", u: Hercegovina, Godišnjak za kulturno i povijesno naslijeđe, 1 (26), Mostar, 2015., str. 93. 
Izanić. ${ }^{2}$ Konstantinova odnosno Šubićka vladavina Humom nije mogla proći bez intervencije srpskoga kralja Milutina. U nekoliko navrata došlo je do sukoba. Je li Milutin koji put uspio zakratko ovladati nekim dijelovima Huma, nije jasno. ${ }^{63}$ Svakako se i on žalio između 1317. i 1321. kao i humski episkop Danilo da je izgubio prihode iz Humske zemlje. ${ }^{64}$ Hum je ponovo 20 -ih godina 14. stoljeća bez pravoga gospodara. Hrvatski ban Mladen II. pao je u nemilost ugarsko-hrvatskoga kralja Karla Roberta, a u Srbiji je umro kralj Milutin. Nesređene prilike u kneštvu pokušala su iskoristiti humska braća Branivojevići koji su u svojim rukama držali Pelješac, primorje kod Slanoga i krajeve uz ušće Neretve te zavladati cijelim kneštvom. Njihovim namjerama na put je stala Dubrovačka Republika i bosanski ban Stjepan II. Kotromanić koji su ih porazili 1326. godine. Pelješcom su od tada vladali Dubrovčani a ostalim dijelom Humskoga kneštva bosanski ban Stjepan II. Kotromanić. ${ }^{65}$ Dubrovčani su svoje posjede htjeli legalizirati te su uskoro stupili u kontakt sa srpskim kraljem Dušanom i bosanskim banom. Najprije su 1333. godine sklopili sporazum sa srpskim kraljem koji im je prepustio Ston s Pelješcem, zemlje od Stona do Dubrovnika i otok Posrednicu na ušću Neretve uz jednokratnu nadoknadu od 8000 perpera i godišnji tribut od 500 perpera. Kako je u to vrijeme stvarni gospodar Humske zemlje bio bosanski ban a ne srpski kralj, Dubrovčani su se obratili i njemu koji im je izdao povelju za Ston i Rât ali bez zemlje od Stona do Dubrovnika i otoka Posrednice uz istu godišnju naknadu kao i srpskome kralju. ${ }^{66}$

Neposredno prije nego što je Humska zemlja došla pod vlast Šubića, između 1297. i 1300. godine, stonskoga je biskupa Petra naslijedio biskup

62 M. Ančić, Na rubu Zapada, str. 159; Mladen Ančıć, Putanja klatna, Ugarskohrvatsko kraljevstvo i Bosna i XIV. stoljeću, Zadar - Mostar, 1997., str. 97; Đ. Tošıć, Trg Drijeva u srednjem vijeku, str. 45; Sima ĆIRKović, Istorija srednjovekovne bosanske države, (ćir.), Beograd, 1964., str. 89.

63 Tošić navodi da je Milutin vladao Drijevima 1306. godine. Đ. Tošıć, Trg Drijeva u srednjem vijeku, str. 44. Ćirković misli da je Milutin 1318. uspio zavladati Humom. S. Ćirković, Istorija srednjovekovne bosanske države, str. 89. Ančić je na osnovi analize izvornih dokumenta i povijesnih okolnosti drugačijega zaključka. On smatra da se mnogo "vjerojatnijom čini postavka o kontinuiranoj vlasti Izanića i vrhovništvu banova Pavla i Mladena II.". M. AnčIć, Putanja klatna, str. 97, 108, posebno na spomenutoj stranici bilj. 6 .

64 Povelja kralja Milutina: Zakonski spomenici srpskih država srednjega veka, str. 597-598; M. Janković, Episkopije i mitropolije Srpske crkve u srednjem veku, str. $40,111$.

65 M. Ančić, Na rubu Zapada, str. 159-160; S. ĆIRković, Istorija srednjovekovne bosanske države, str. 89-90.

66 S. ĆIR коvić, Istorija srednjovekovne bosanske države, str. 92. 
Ivan Kružić. O njegovu djelovanju u stonskoj biskupiji izvori šute. ${ }^{67} \mathrm{Lu}-$ ccari, početkom 17. stoljeća, donosi podatak da je neki biskup Ivan stanovao kod Sv. Marije u polju. Je li ovo Luccari napisao pretpostavljajući ili na temelju tradicije ili je naišao na neki nama nepoznati podatak, nije poznato. Luccari također piše da su, dok je Stonskom crkvom upravljao biskup Ivan, "niže redove" držali raški monasi u Sv. Nikoli. ${ }^{68} \mathrm{O}$ kojemu je biskupu Ivanu riječ, nije jasno jer se u isto vrijeme spominje stonskokorčulanski biskup Ivan i "humski episkop Ivan". ${ }^{69}$ Ovaj se posljednji spominje u priznanici kojom je kralj Milutin potvrdio darovnicu svoje majke Jelene benediktinskome samostanu sv. Marije na Rtacu, a Miklošić je datira između 1305. i 1307. godine. ${ }^{70}$ Zanimljivo je da se u društvu "episkopa" Ivana kao svjedoci potvrde, koja je izdana u Kotoru, spominju dva katolička nad/biskupa i jedan pravoslavni. Katolički su bili barski nadbiskup Marin i kotorski biskup Dujam, a pravoslavni zetski episkop Mihajlo. Na kojega je Luccari mislio ostaje nam nejasno. Iz njegove formulacije moglo bi se zaključiti, a on ovo piše kada je već bila jasna razlika između katolika i pravoslavnih, da se radilo o katoličkom stonsko-korčulanskom biskupu Ivanu. Za monahe piše da su "Rašani" te da je Republika bila odlučila da odu, dok za biskupa ne piše da je "Rašanin" niti da je za njega odlučeno da ide. ${ }^{71}$ Monahe i njihov odlazak spominje

67 Foretić tvrdi, premda za to ne donosi jasne dokaze nego samo uobičajene političke prilike koje ne bi izdržale kritiku današnje historiografije, da biskup Ivan nije vršio biskupsku vlast nad Stonskim râtom. Vinko Foretić, Otok Korčula u srednjem vijeku do g. 1420., Zagreb, 1940., str. 73; VInKo Foretić, "Kroz prošlost poluotoka Pelješca", u: Spomenica Gospe od Anđela u Orebiću 1470-1970, Omiš, 1970., str. 259.

68 "La cura della chiesa di Stagno haveva il vescovo Gioanni, che stanziava à Santa Maria del piano, sua diocesi, ma l'ordinazioni minori tenevano i monaci Rassia in san Nicolo. Ma perche la Republica desiderava totalmente ridur il popolo al rito Romano, però si dispose à farli partire." Giacomo Pietro Luccari, Copioso ristretto degli annali di Ravsa', Venezia, 1605., str. 55.

69 Je li se možda radilo o istoj osobi? Čudna koincidencija imena bi mogla upućivati na daljnje istraživanje!

70 Monumenta Serbica, str. 67-69.

71 Foretić biskupa Ivana, kojeg spominje Luccari, poistovjećuje s humskim episkopom Ivanom koji se spominje u potvrdi kojom je kralj Milutin potvrdio darovnicu svoje majke Jelene benediktinskome samostanu sv. Marije u Rtacu. Dalje navodi da je u "crkvi-manastiru sv. Marije bilo sjedište pravoslavnog episkopa". V. Foretić, "Kroz prošlost poluotoka Pelješca", str. 271, bilj. 30. Samostan svete Marije na Rtacu bio je benediktinski samostan i nikad nije bio sjedište pravoslavnoga episkopa. Ivan Marković, Dukljansko-barska Metropolija, Zagreb, 1902., str. 105-106. Hrvatski prijevod Milutinove potvrde. Isto, str. 106-108. Slijepčević je mišljena da je riječ o katoličkom biskupu. Đ. SLIJEPČEvić, "Humsko-hercegovačka eparhija i episkopi (mitropoliti) od 1219. do kraja XIX. veka", str. 114. 
i Linanova pergamena, o kojoj će kasnije biti govora, ali biskupa i njegov odlazak ne spominje. Koegzistencija katoličkoga biskupa i "monaha Rašana" u to je vrijeme bila moguća. Deveti kanon IV. lateranskoga koncila 1215. odredio je, a ova odluka nije dokidana na sljedećim koncilima, da biskupi u biskupijama u kojima žive narodi različitih jezika, obreda i običaja provide "prikladne muževe" koji će različitim obredima i jezicima slaviti Božju službu i dijeliti sakramente tim narodima. ${ }^{72}$

Biskup je Kružić u dogovoru s Korčulanima 1300. odlučio biskupsko sjedište prenijeti iz Stona na Korčulu što je papa Bonifacije VIII. (1295.1303.) godine 1301. odobrio. ${ }^{73}$ Premda je prenio biskupsko sjedište u Korčulu, nije se odrekao kao ni njegovi nasljednici Stonske biskupije, pa je moguće da je biskup Kružić povremeno, kada su mu prilike dopuštale ili služba zahtijevala, boravio u Stonu. U vrijeme Kružićevih nasljednika zahumski episkop Danilo žali se kralju Milutinu da su mu opustjeli prihodi Humske zemlje. Posljednji zahumski episkop Stefan spominje se 1330. godine. U vrijeme prodaje Stona i Râta 1333. nema spomena nikakvu episkopu, a čini se da se i eparhija u to vrijeme gasi. Darovnica kralja Dušana manastiru sv. Petra na Limu 1343. godine isključuje postojanje episkopskoga sjedišta čak i na Limu. M. Janković smatra da je humska episkopija dokinuta 1333.-1334. godine te da je već od 1317. do 1324. izgubila svaku vezu s Humom i Stonom. ${ }^{74}$

\subsection{Zatečeno stanje 1333. godine}

Iz navedenoga je jasno da se od 80 -ih godina 13. stoljeća na humskom području bilježi prisutnost katoličkoga stonskog biskupa, a da se ona zahumskoga pravoslavnog od sredine 13. stoljeća umanjuje da bi konač-

72 "Quoniam in plerisque partibus intra eamdem civitatem atque dioecesim permixti sunt populi diversarum linguarum, habentes sub una fide varios ritus et mores: districte praecipimus, ut pontifices hujusmodi civitatum sive dioecesum provideant viros idoneos, qui secundum diversitates rituum et linguarum Divina officia illi celebrent, et ecclesiastica sacramenta ministrent, instruendo eos verbo pariter et exemplo." Sacrorum conciliorum nova et amplissima collectio, vol. 22, str. 998. Da je bilo takvo nešto moguće i u Visokim Dečanima i to u vrijeme srpskih kraljeva Stjepana Uroša III. Dečanskog i Dušana, govori podatak o glavnom arhitektu ovoga manastira fra Ivanu iz Kotora koji je cijelo vrijeme gradnje živio s tamošnjim monasima i slavio misu na latinskom obredu. Niko Ikić, Petrovska služba stijena jedinstva i kamen spoticanja, Sarajevo - Zagreb, 2015., str. 77-78.

73 Ugovor biskupa Kružića i Korčulana: Illyrici sacri, VI., str. 329.

74 M. Janković, Episkopije i mitropolije Srpske crkve u srednjem veku, str. 112, bilj. 40; B. Nilević, Srpska pravoslavna Crkva u Bosni i Hercegovini do obnove Pećke patrijaršije 1557. godine, str. 35. 
no 30-ih godina 14. stoljeća i eparhija bila dokinuta. Postavlja se pitanje kako pomiriti ovu prisutnost katoličkih stonskih biskupa sa zahtjevom kralja Dušana Dubrovčanima 1334. da pop srpski prebiva u Stonu i Râtu i da "poi-e" po tamošnjim crkvama? Čini se da se u kraljevu zahtjevu više radilo o reminiscenciji ili o pokušaju zadržavanja utjecaja nego o stvarnom stanju, odnosno o tome da je srpska Crkva te prostore još uvijek smatrala svojom jurisdikcijom iako je s njima bila izgubila svaki kontakt kao što je i Dušan bio izgubio Humsku zemlju premda ju je još uvijek smatrao svojom. Dubrovčanima je osim Stona i Râta prodao i zemlje od Stona do Dubrovnika i otok Posrednicu što nije imalo nikakva stvarnoga učinka. Ako je uistinu postojao "pop" koji je 1334. priznavao jurisdikciju srpskoga episkopa (čudno da nema riječi o monasima), trebalo bi protumačiti kojega episkopa ako se u to vrijeme, kao što je već rečeno, Humska eparhija gasi, a Mileševska se mitropolija javlja tek krajem 14. stoljeća, i to na prostoru Dabarske episkopije a ona Limska tek krajem 15. stoljeća. Zar nije bilo logičnije da su monasi i svećenstvo Humske zemlje, konkretno Stona i Râta, priznavali jurisdikciju stonskokorčulanskoga biskupa, jurisdikciju koja je dopuštala različitost obreda? $\mathrm{K}$ tomu još treba napomenuti da je utjecaj srpskih kraljeva na Humsku zemlju pa tako i na Ston i Rât od početka 14. stoljeća bio gotovo neznatan te da do pred kraj vladavine kralja Milutina, osobito dok je živjela kraljica majka Jelena, na ovim prostorima nije bilo nekih vjerskih trvenja. Neke radikalne promjene nisu smjeli uvoditi ni stonski biskupi a za to nisu ni imali potrebe jer se različitost jezika i obreda nije kršila s priznavanjem njihove jurisdikcije. To što je biskup Kružić 1300. godine premjestio biskupsku stolicu na Korčulu, treba vezati više uz njegovu želju za boljim i ugodnijim životom nego s neprijateljstvom "heretika" i "raskolnika". Svakako je biskupu bilo ugodnije živjeti na Korčuli nego na nemirnom humskom području prvih desetljeća 14. stoljeća. Neko Kružićevo izvješće o vjerskim prilikama u Stonskoj biskupiji, koje se koristi kao argument o postojanju raskolnika i heretika u Stonu i Râtu, uopće ne postoji. Već na prvi pogled u tekst koji se nalazi u Illyrici sacri na koji se nerijetko poziva, jasno daje do znanja da to nije tekst biskupa Kružića nego pisca 6. sveska Illyrici sacri talijanskoga isusovca Jakova Colettija (1734.-1827.). ${ }^{75}$ U ugovoru između biskupa Kružića i Korčula-

75 Illyrici sacri, VI., str. 328. Da je ovaj tekst pisao biskup Kružić a ne isusovac Coletti, pišu oslanjajući se na Illyrici sacri, str. 328: A. DračEvac, "Ponovno osnivanje katoličke biskupije u Stonu", str. 83; I. PuljIć, "Crkvene prilike u srednjovjekovnoj Humskoj zemlji", str. 130; D. Korać, Vjera u Humskoj zemlji, str. 27. Vinicije Lupis i Josip Sopta donose čak i svoje prijevode teksta u prvom licu: VINICIJE LuPIS, "Pregled povijesti Stonske biskupije od osnutka do 1541. godine", u: Tisuću godina 
na nema nikakva spomena ni o "hereticima" ni o "raskolnicima", nego samo o boljim uvjetima života koje je Korčula nudila biskupu za njegov prelazak na otok. ${ }^{76}$

Što kažu dokumenti poslije 1334. godine? U prvim godinama Dubrovačke vladavine Stonom i Râtom u Odlukama vijeća Dubrovačke Republike koje su očuvane od 1335. nema nikakva spomena pravoslavnih na poluotoku. Nikakva odluka Republike iz 1346. godine da u Stonu i Râtu ne smiju prebivati pravoslavni svećenici na koju se neki pozivaju, u izvorima nije pronađena. ${ }^{77}$ Liepopili piše da je pregledao sve moguće dokumente toga vremena i da tu odluku nigdje nije pronašao. ${ }^{78}$ Nije je nitko ni poslije njega pronašao. ${ }^{79}$ To što se spominju slavenski svećenici - "presbitero Slauo" - u Odlukama vijeća Dubrovačke Republike ne mora značiti, kao što smatraju neki povjesničari, da su automatski time što su bili "Slavi" bili i pravoslavni svećenici. ${ }^{80}$ Bilo bi korektnije i u skladu

Dubrovačke (nad)biskupije, str. 209; Josıp Sopta, "Franjevci Bosanske vikarije na području Dubrovnika", u: Hercegovina, Godišnjak za kulturno i povijesno naslijeđe, 6-7 (14-15), Mostar, 2000.-2001., str. 176. Tekst je pisan u trećem licu i doslovno glasi: "Totam peninsulam haereticis et schismaticis refertam reperit, qui non solum salutaria ejus monita respuebant, sed etiam iniquis infestisque animis illum intuebantur; et quae sapienter pieque ad depravatos incolarum mores corrigendos, ac disciplinam ecclesiasticam restituendam decernebat, ea ne perficere posset, pertinaciter obstabant. Praeterea proventus Mensae Episcopalis magna ex parte interveterant; vix ut illi quae satis essent ad victum cultumque suppeterent. Cum igitur inter homines adversos, atque infensos Catholicae fidei nec sibi tuto et quieto esse liceret, nec rei Christianae bene gerenda facultas daretur, Sedis Pontificiae alio transferendae consilium coepit." Illyrici sacri, VI., str. 328.

76 Illyrici sacri, VI., str. 329.

77 Odluku donosi Nikodim Milaš riječima: "Senat uvaži žalbu fratara, i u početku 1346. godine izda naredbu, da ni jedan 'šizmatički duhovnik' ne smije više biti ni u Stonu, niti u ikakvom drugom mjestu poluostrva." Nikodim Milaš, Ston u srednjim vijekovima: crkveno-istorijska studija, (ćir.), Dubrovnik, 1914., str. 100. Isti autor piše da je odluka ponovljena 1355. godine. OndJE, str. 106. Prvu odluku navodi i Korać. D. Korać, Vjera u Humskoj zemlji, str. 83.

78 A. LIEPOPILI, Ston u srednim vijekovima: crkveno-istorijska studija na odgovor Episkopu Nikodimu, Dubrovnik, 1915., str. 72-73.

79 J. ŠIDAK, "Vjerski odnosi u Stonu i na Stonskom ratu (Pelješcu) u srednjem vijeku", str. 281, bilj. 28.

80 Navest ćemo samo neke: K. JiReČeK, Istorija Srba, I., str. 266; N. Milaš, Ston u srednjim vijekovima, str. 101; V. Ćorović, "Značaj Humske eparhije", str. 56; V. Foretić, "Kroz prošlost poluotoka Pelješca", str. 265-269; J. ŠidaK, "Vjerski odnosi u Stonu i na Stonskom ratu (Pelješcu) u srednjem vijeku", str. 281; NENAD VeKarić, Stanovništvo poluotoka Pelješca, I., Dubrovnik, 1992., str. 16-17; D. KoRAĆ, Vjera u Humskoj zemlji, str. 87. Korać na temelju Dinića: Iz dubrovačke ar- 
s izvorima i ondašnjim poimanjem Crkve pod ovim pojmovima razumjeti svećenika iz dubrovačkoga zaleđa koji je službu Božju obavljao na slavenskome jeziku, istočnoga ili zapadnoga obreda. Kada odluke dubrovačkih vijeća spominju imena ovih svećenika, a to su bili Bratoslav, ${ }^{81}$ Ilija i Milat, uz njihova imena nema nikakve naznake da se radi o "raskolnicima". Da su doista bili "raskolnici", nema razloga da vijećnici to ne bi naveli osobito nakon pobune koja je izbila u Stonu i Râtu 1346. godine zbog koje su ovi svećenici bili nakratko, osim Milata koji je bio trajno, protjerani. Osim toga, Dubrovniku su dobro poznati slavenski svećenici. Još 80-ih godina 14. stoljeća bilo ih je u Župi, Gružu, Zatonu, Rijeci i Šumetu te na nekim otocima. ${ }^{82}$ U Ston se ponovo vraćaju krajem istoga stoljeća nakon što su Dubrovčani riješili spor sa stonskokorčulanskim biskupom. Dubrovačko Veliko vijeće dalo je 27. srpnja 1392. na slobodu Rektoru i Malom vijeću da mogu pozvati "presbiteros sclavichos - slavenske svećenike" i postaviti ih na području Dubrovnika i Stonskoga râta tamo gdje im se čini da je potrebno. ${ }^{83}$ To što su oni protjerani nakon pobune 1346. te im je ponovo bio dopušten povratak osim, kako je već rečeno Milatu, 1347. nema nikakve veze s njihovom crkvenom pripadnošću. Pobuna je izbila zbog radikalnih promjena koje je Republika zavodila u Stonu i na Râtu, osobito zemljišnih, u kojima su bivši vlasnici postali kmetovi novih vlasnika, dubrovačke vlastele. ${ }^{84} \mathrm{Mo-}$ guće je da su u ovim radikalnim promjenama koje su se događale i na crkvenome području, jer upravo u to vrijeme Republika dovodi u Ston i Stonski rât strane svećenike, spomenuti svećenici ostali bez službe te su se pridružili pobunjenicima. To što se 1394. spominje Pribac, sin svećenika Bratoslava, nije nemoguće da je Bratoslav, ako je bio istočnoga

hive donosi da se kaluđer Bratoslav spominje 1365. kad je imenovan tutorom nekoj Maruši. D. Korać, Vjera u Humskoj zemlji, str. 87. Međutim, u originalnom dokumentu se spominje "caligarius - obućar". Minajlo Dinić, Iz dubrovačkog arhiva, sv. I., Beograd, 1967., str. 13.

81 Za Bratoslava Foretić piše da je bio "episkopski namjesnik" premda za to ne navodi nikakav izričit izvor. V. Foretić, "Kroz prošlost poluotoka Pelješca", str. 266.

82 A. Liepopili, "Slavensko bogoslužje u Dubrovniku", str. 44-58.

83 "1392. 27./ 7. Prima pars est de dando arbitrium et liberam auctoritatem domino Rectori et eius minori consilio presentibus et futuris inveniendi presbiteros sclavichos et ipsos ponendi per districtum Ragusii et punctam Stagni ubi eis videbitur cum salario, modis et conditionibus quibus melius poterunt et eis videbitur utilius." A. LiepopıLI, "Slavensko bogoslužje u Dubrovniku", str. 47.

84 Kao vjersku pobunu prvi ju je okarakterizirao Milaš. N. Mılaš, Ston u srednjim vijekovima, str. 101-103. Suprotno kao gore u tekstu: A. LiePoPILI, Ston u srednjim vijekovima, str. 72; V. Foretić, "Kroz prošlost poluotoka Pelješca", str. 276-277. 
obreda, bio i oženjen. ${ }^{85} \mathrm{Da}$ je mogao biti oženjen, govori već spomenuta odredba IV. lateranskog sabora iz 1215. godine gdje je rečeno da svećenici, koji se "po običaju zemlje" nisu odrekli žene, mogu nastaviti živjeti u zakonitome braku. A da je mogao biti oženjen čak i kao svećenik zapadnoga obreda, govori koncil u Vienneu, 1311.-1312. godine, u dekretu Diocesanis locorum, koji je saborski dekret ili blisko s njim povezan. Ovim dekretom bilo je zabranjeno svećenicima da budu mesari i gostioničari. U slučaju neposlušnosti "izgubili bi svećenički privilegij ako bi bili oženjeni; a ako ne bi bili, izgubili bi realni privilegij svećenika i također osobni privilegij, jer su se ponašali u svemu kao laici". ${ }^{86}$ Ako je bilo moguće u to vrijeme biti oženjen na Zapadu, još je veća mogućnost za to bila na ovome graničnom prostoru. Osim toga, da su ovi svećenici uistinu bili "raskolnici", odnosno da su priznavali jurisdikciju srpskoga episkopa, jer raskolništvo se veže uz jurisdikciju, bilo bi logičnije da su se povukli na prostor njegove jurisdikcije i ondje djelovali nego da su ostali u Stonu i Râtu.

To što su Dubrovčani dovodili svećenike s drugih strana i fratre Bosanske vikarije u Ston i Rât, čini se da se mora promatrati u kontekstu njihova odnosa prema stonsko-korčulanskome biskupu a ne u kontekstu potrebe obraćenja tamošnjih stanovnika na katoličanstvo. Dubrovačko Malo vijeće odlučilo je 22. kolovoza 1335. da se za Ston izabere svećenik s jednim pomoćnikom koji će Božju službu i ostale sakramente slaviti "u Stonskoj biskupiji (naglasio M. K.) ..., kako određuje majka rimska Crkva" o trošku stonskoga kneza i Republike. ${ }^{87}$ Desetak godina poslije, u kolovozu 1346., izabrali su za svećenika u Stonu nekoga Albanca, najvjerojatnije svećenika Nikolu, koji se spominje dva mjeseca poslije. Njemu je Malo vijeće odredilo da "od općine - a communi" ima primati

85 K. JiRIČEK, Istorija Srba, I., str. 266. KonstAntin JiReČEK, "Dohodak stonski, koji su Dubrovčani davali srpskom manastiru sv. Arhangjela Mihajla u Jerusalimu i povelje o njemu cara Uroša (1358) i carice Mare (1497)", u: Zbornik u slavu Vatroslava Jagića, Berlin, 1908., str. 530. Među njegovim nasljednicima se kasnije spominje don Petar Stanojević iz Stona. Isto.

86 "In caso di disobbedienza, essi avrebbero perso il privilegio clericale, se fossero stati sposati; se non lo fossero stati, avrebbero perso i privilegi 'reali' dei chierici e anche i privilegi 'personali', essendosi comportati in tutto come dei laici." JosEPH LeCler, Storia dei concili ecumenici, Vienne, Città del Vaticano, 1997., str. 144.

87 "In minori consilio captum ... quod in Stagno debeat eligi unus presbiter, qui teneatur celebrare divina offica in episcopatu Stagni, cum uno clericello, et recipere eos ad confessionem, et dare eis penitentiam et alia divina officia, prout precipit sancta mater ecclesia Romana, ..." Monumenta Ragusina, Libri reformationum, II., A. 1347-1352, 1356-1360. Additamentum a. 1301-1305, 1318, 1325-1336., Zagrabiae, 1882., str. 360 . 
prvu godinu 30 perpera kao pomoć za obrađivanje vinograda koji se nalazio kod samostana te poslije svake godine, dok tu bude, 10 perpera i prihode spomenutoga vinograda ${ }^{88}$ Sljedeće godine susrećemo istoga svećenika Nikolu, a već početkom kolovoza 1348. svećenika Petra također Albanca. ${ }^{89}$ Izbor svećenika Albanaca, uz obilje domaćih svećenika koje je Dubrovačka nadbiskupija u to vrijeme sigurno imala, naznačuje da se radilo o veoma delikatnom crkvenom poslu. Vjerojatno s istom namjerom Dubrovčani su u Ston doveli i fratre Bosanske vikarije koji su, zbog svojih privilegija, u mnogočemu bili izuzeti ispod jurisdikcije biskupa. Kada su točno fratri došli u Ston, nije poznato. Dozvolu za gradnju samostana u Stonu dobili su 21. ožujka 1347. od pape Klementa VI. (1342.-1352.), a od Dubrovačke Republike 18. veljače 1349. ${ }^{90}$ Vjerojatno su došli koju godinu prije.

Spomen pravoslavnih u Stonu i na Stonskome râtu susreće se tek u okviru katoličke rasprave odnosno spora koji je nastao između Dubrovnika i stonsko-korčulanskih biskupa zbog jurisdikcije nad Stonom i Râtom. Dubrovčani nisu nikad iskreno, premda službeno jesu 1387., priznali jurisdikciju stonsko-korčulanskom biskupu na Stonu i Râtu. ${ }^{91}$ Kada je stonsko-korčulanski biskup Marin, franjevac iz Spoleta iz Italije, negdje 1341.-1342. pokušao vršiti svoje biskupske dužnosti u Stonu i na Râtu, u tome su ga spriječili, kako je on pisao papi Klementu VI. (1342.-1352.), a papa Dubrovčanima 1344. "neki iz onih krajeva za koje se govorilo da su bili zaraženi osudljivim raskolom Rašana" pod čijom su vlašću bili do posljednjih deset godina, ali "okanivši se nekako zabluda, našem su se putu spasenja i istine vratili" te neki građanin i sudac Dubrovačke Republike koji je zbog toga bio poslan u Ston i Rât od same Republike. ${ }^{92} \mathrm{Iz}$

88 Monumenta Ragusina, Libri reformationum, I., str. 239, 245.

89 Monumenta Ragusina, Libri reformationum, II., str. 35.

90 A. DračEvac, "Ponovno osnivanje katoličke biskupije u Stonu", str. 85. Sopta drži da su u Ston došli oko 1330. ali za to ne navodi jasne dokaze. J. Sopta, "Franjevci Bosanske vikarije na području Dubrovnika", str. 181.

91 O sporu Dubrovnika sa stonsko-korčulanskim biskupima: Vinko Foretić, Otok Korčula u srednjem vijeku do g. 1420., str. 83-88 i 113-118; VINICIJE Lupis, "Pregled povijesti Stonske biskupije od osnutka do 1541. godine", u: Tisuću godina Dubrovačke (nad)biskupije, str. 211-212.

92 "... nonnulli de partibus illis, qui dampnando scismate Rassiencium, sub quorum seruitute a decem annis proximopreteritis supra multis temporibus steterant infecti dicebantur, quodam modo relictis erroribus ad nostram salutis et ueritatis redirent, quidam ciuis et iudex ciuitatis Ragusine se a dilectis filiis comite, iudicibus, consilio et vniuersitate missu vna cum quibusdam aliis ad partes Stangnenses predictas, ... ." Klement VI. Dubrovačkoj Republici 22. 2. 1344. Codex diplomaticus, XI., str. 118. 
riječi biskupa Marina koje su nastale ni deset godina nakon Dušanove povelje, ako ih je Rimska kurija vjerodostojno prenijela, a u to nemamo razloga sumnjati, vidimo da nema spomena ni o kakvim "raskolničkim" svećenicima ni "raskolnicima". Postojali su samo "neki", ne svi kako će kasnije isticati Dubrovčani, "iz onih krajeva za koje se govorilo (naglasio M. K.) da su bili zaraženi osudljivim raskolom Rašana", ali kako vidimo i oni su se već u to vrijeme (terminus ante quem) bili vratili "našemu putu spasenja i istine". Valja napomenuti da su u vrijeme, kada je biskup Marin pokušao vršiti svoju službu u Stonu i Râtu, još uvijek bili gore spomenuti slavenski svećenici koje biskup ne spominje. Popu Bratoslavu je Vijeće umoljenih samo godinu prije biskupove vizitacije 1340. godine potvrdilo neke crkve i njima pripadajuća zemljišta. ${ }^{93} \mathrm{Da}$ ga je biskup doživljavao kao "raskolnika", vjerojatno bi ga spomenuo i ovaj čin Dubrovčana osudio - njemu uskraćuju desetine a Bratoslavu daruju crkve i zemlju. Ni biskup Ivan, koji je bio s Krka, 70-ih godina 14. stoljeća nije bio uvjeren da su njegovi vjernici do 30-ih godina 14 . stoljeća bili "raskolnici". On se žalio papi Grguru XI. (1370.-1378.) da mu vjernici Stona i Stonske biskupije uskraćuju desetinu i druga biskupska prava navodeći kako su ti isti vjernici "od davnih vremena unatrag bili raskolnici i nevjernici", ali "priznavši pravu katoličku vjeru" bili su se vratili u jedinstvo Crkve te da su ti spomenuti Stonjani i Raćani "nekog sina bezakonja, koji je već dugo po obredu Grka i raskolnikâ držao zauzetima episkopat i Crkvu stonsku, istjerali iz spomenutoga grada i biskupije". ${ }^{4}$ Izraz "od davnih vremena unatrag" sugerira da to nije bilo prije 50-ak godina nego puno prije. Također biskup, što je bilo u skladu s teološkim i crkvenim poimanjem, raskolništvo Stonjana i Raćana veže uz jurisdikciju "raskolničkog biskupa" - "sina bezakonja" te njihovo vraćanje jedinstvu Katoličke crkve povezuje s trenutkom kada je on protjeran i kada oni više nisu priznavali njegovu jurisdikciju. Međutim, drugačiju priču od ove pričaju tadašnji Dubrovčani. Oni su u sporu sa stonsko-korčulanskim biskupom angažirali pravnoga stručnjaka Ivana de Lignano iz Bologne koji je trebao zastupati njihovu parnicu pred Svetom Stolicom. Da bi u tome uspjeli, morali su uvjeriti Svetu Stolicu u svoje velike zasluge za katoličanstvo, kako su to obično činili, a kao dobar argument moglo je poslužiti obraćenje "raskolnika". Pravnik je Ivan, što je bilo logično, informacije primao od Dubrovčana tako da u njegovu izvješću poznatom pod imenom Linanova pergamena stoji da su Dubrovčani obećali srpskom kralju da kaluđere i slavenske svećenike

93 V. Foretić, "Kroz prošlost poluotoka Pelješca", str. 270, bilj. 30.

94 Urban VI. trebinjskom biskupu da riješi slučaj biskupa Ivana 24. studenoga 1378. Codex diplomaticus, XV., str. 305. 
koji su stanovali u Stonu ne će prisiljavati na odlazak ali s vremenom kako su Dubrovčani kršćani i katolici a Ston se nalazio u njihovu posjedu, kršćani i Kristovi vjernici umnažali su se tako da su "kaluđeri raskolnici i slavenski svećenici" sami napustili Ston, a Dubrovčani su tamo postavili katoličke i vjerne svećenike te potom sagradili samostan fratrima Bosanske vikarije i tako su konačno svi stanovnici "spomenutih mjesta" postali vjerni i pravi katolici zahvaljujući fratrima koji su za ovo imali posebne povlastice. ${ }^{95}$ Sadržaj Linanove pergamene kosi se sa žalbom biskupa Marina iz 1342.-1343. i djelovanjem slavenskih svećenika na Poluotoku. Kao što smo vidjeli, u žalbi biskupa Marina stoji da su se već u njegovo vrijeme "neki za koje se govorilo da su bili zaraženi osudljivim raskolom Rašana" već bili vratili jedinstvu Katoličke crkve a to je bilo i nekoliko godina prije nego što su franjevci dobili dozvolu za gradnju samostana u Stonu. Osim toga, slavenski svećenici, kao što smo gore vidjeli, nisu bili napustili Ston i Rât nego su na njemu ostali, osim ako se nije radilo o nekim drugim svećenicima koje dokumenti ne spominju. Valja spomenuti i franjevačku spomenicu iz 1394. godine. Ona, osim "raskolnika", spominje i "patarene" te kaže da su Ston i Rât bili podložni spomenutima "dobrih trista godina" te da ni u Stonu ni na Râtu nije bilo spomena o katoličkom kultu dok oni nisu došli koji su taj narod obratili i pokrstili. ${ }^{96}$ I spomenica je nastala nakon što su franjev-

95 Izvadak iz Linanove pergamene: "Item fuit promissum per dictos Cives predicte Civitatis Ragusii domino Regi Rassie quod calogeri qui habitant in dicto loco Stagni et sacerdotes sclavi non cogerentur ad recessum nisi sponte recederunt. Item erat dictus locus quasi incultus licet habitaretur per scismaticos. Item in processu temporis cum Ragusini sint christiani et catholici et dictum locum possiderent et continuo christiani et fides Christi illic multiplicaretur predicti Calogeri scismatici et sacerdotes sclavi sponte recesserunt et predicti Cives Ragusini ibi posuerunt sacerdotes catholicos et fideles, deinde construxerunt monasterium et locum fratribus minoribus de Vicaria bosne, et sic factum est finaliter usque modo quod omnes habitatores predicti loci sint fideles et veri catholici et ecclesiastica sacramenta recipiunt a predictis fratribus minoribus habentibus super hec privilegium spetiale". A. Liepopili, Ston u srednjim vijekovima, str. 32 . O vjerodostojnosti dubrovačkih dokumenata o ovom problemu valja spomenuti i slučaj iz 1422. godine. Te su, naime, godine Dubrovčani poslali u Rim fra Lovru Menčetića zbog ponovnog spora između Dubrovčana i stonsko-korčulanskog biskupa. Fra Lovro je trebao prikazati stanje u Stonu i na Râtu sljedećim riječima: "et come per nostra spesa e opera quel luogo siando paterino e facto catholico". V. Foretić, "Kroz prošlost poluotoka Pelješca", str. 267, bilj. 28. U uputi Dubrovčana fra Lovri nema nigdje spomena o "raskolnicima". Može se pretpostaviti je da su "patareni" u to vrijeme bili uvjerljiviji argument od "raskolnika".

96 Acta Bosnae potissimum ecclesiastica cum insertis editorum documentorum regestis ab anno 925 usque ad annum 1752., P. Eusebius FermendžIn, (collegit et digessit), Zagrabiae, 1892., str. 54-55. 
cima u vrijeme dubrovačkoga nadbiskupa Petra (1370.-1380.) oduzete župe te je trebala također poslužiti da prikaže velike zasluge stonskih franjevaca za ovdašnje katoličanstvo tako da podatcima koje ona donosi treba pristupiti s velikim oprezom kao i prema Linanovoj pergameni. Čini se dovoljnim spomenuti kako ona govori da su spomenuti krajevi "dobrih trista godina" bili podvrgnuti "raskolnicima i patarenima" a to bi značilo već od kraja 11. stoljeća i da na Stonu i Râtu prije njihova dolaska nije bilo spomena o katoličkom kultu. Spominjanje "patarena" ili "nevjernika" u Stonu i Râtu do 1333. ukazuje također na nategnutost ovoga dokumenta. Poznato je da se ova "hereza" širila na područjima pod vlašću bosanskih vladara, a Ston i Rât nikada nisu bili pod njihovom vlašću tako da se ona ondje nije ni mogla ustaliti. ${ }^{97}$ Osim toga spomenica navodi ponovno krštavanje "raskolnika" što Katolička crkva nikada nije imala u svojoj praksi.

Linanovu pergamenu i Franjevačku spomenicu ipak ne treba potpuno odbaciti. Nešto se ipak o onome što ova dva dokumenta govore događalo u Stonu i Râtu a to je, moglo bi se zaključiti, uvođenje rimskoga obreda na latinskom jeziku. Republika se nalazila u "moru" nemirnoga i trusnoga slavenstva. Sve što je moglo nove prostore rastaviti od njegova prirodnoga zaleđa i čvršće ga vezati uz Republiku dobro je došlo. U tom je smislu trebao poslužiti i rimski obred na latinskom jeziku. Kada su Dubrovčani 1335. odredili da se za Ston izabere jedan svećenik s pomoćnikom, odredili su također da taj svećenik u Stonskoj biskupiji treba slaviti obrede "kako određuje majka rimska Crkva"..$^{8}$ Isti ih je razlog vjerojatno vodio i za dovođenje franjevaca Bosanske vikarije koji su također obrede slavili po rimskom obredu latinskim jezikom. Osim toga, franjevci su kao misionari u mnogočemu mogli biti izuzeti ispod biskupove jurisdikcije. Ovakva je mišljenja bio i Luccari početkom 17. stoljeća. Pišući o biskupu Ivanu koji je vodio brigu o Stonskoj Crkvi i raškim monasima koji su u njegovo ime obavljali niže obrede nastavlja: "Ali jer je Republika željela potpuno privesti narod rimskom obredu, odlučila je da [monasi] odu. To je lako postigla dajući im za dostojan način življenja u samostanima Makedonije, i na njihovo je mjesto dovela Braću svetoga Franje". ${ }^{99}$ Republika je vrlo lako, a da ne odstupa puno od istine, ovaj proces mogla kasnije u sukobu sa stonsko-korčulanskim biskupom prikazati kao proces obraćenja "raskolnika". Kasnije je u tu

97 O tome opširnije: J. ŠIDAK, "Vjerski odnosi u Stonu i na Stonskom ratu (Pelješcu) u srednjem vijeku", str. 275-289.

98 Monumenta Ragusina, Libri reformationum, II., str. 360.

99 G. P. Luccari, Copioso ristretto degli annali di Ravsa', str. 55. 
svrhu koristila "patarene". Osim toga, ovi su krajevi zbog nemirnih prilika, promjenâ jurisdikcija, arogantna odnosa mjesnih moćnika prema Crkvi, nebrige crkvenih prelata, kako zapadnih tako i istočnih jer se mnogo toga svodilo na prihode, pod vodstvom neškolovana svećenstva dobrim dijelom bili vjerski zapušteni. Njihovo vjersko stanje možda je najbolje opisao dubrovački anonimni kroničar s početka 16. stoljeća kada piše da su ljudi na cijelom Stonu i Râtu bili vjere "raskolničke" "jer nisu vjerovali ni u Boga, ni u svece nego su vjerovali u snove, vračare i čarobnjake". ${ }^{100}$ Shvaćajući u ovom smislu "raskolništvo" i Dubrovčani i franjevci su u Stonu doista mogli imati posla oko obraćenja "raskolnika" i "nevjernika" u "rimsku" Crkvu i vjeru.

\section{Zaključak}

Prostori Humske zemlje do kraja 12. stoljeća bili su u jurisdikciji stonskoga katoličkog biskupa. Uz latinski u liturgiji je korišten i slavenski jezik koji je, čini se, bio prevladavajući. Kako je prostor biskupije bio na razmeđu Istoka i Zapada dolazilo je do "miješanja" zapadnoga i istočnoga obreda. Krajem 12. stoljeća, kada je Humska zemlja došla pod vlast kneza Miroslava Nemanjića, stonski katolički biskup je prognan. Na njegovo mjesto došao je u vrijeme osnivanje srpske pravoslavne arhiepiskopije 1219. episkop koji je priznavao jurisdikciju srpskog pravoslavnog arhiepiskopa te su tako ovi prostori došli pod utjecaj istočne Crkve. $\mathrm{Na}$ terenu se stvari nisu bitno promijenile zbog bliskosti jezika i obreda. Uz humskoga pravoslavnog episkopa u Stonu koegzistiraju benediktinci mljetskoga samostana sv. Marije. Zbog nestabilnih političkih prilika humski je episkop sjedište eparhije sredinom 13. stoljeća premjestio u manastir sv. Petra na Limu. Sredinom 80-ih godina ponovo je imenovan stonski katolički biskup. Kako je Katolička crkva priznavala različitost jezika i obreda ponovno su koegzistirali, sada sa zamijenjenim ulogama, katolički biskup i istočni "raški" monasi i svećenstvo koje je službu slavilo na slavenskom jeziku i, vjerojatno, istočnim obredom. Kada su Ston i Rât došli pod vlast Dubrovčana dolazi do velikih promjena. Dubrovčani želeći stanovništvo Stona i Râta što više vezati uz Republiku i ujedno zapriječiti stonsko-korčulanskom biskupu vršenje njegove jurisdikcije na Stonu i Râtu dovode strane svećenike i franjevce (strance?) Bosanske vikarije koji uvode "rimski" obred i latinski jezik u bogoslužje. Nastaje sukob između Dubrovčana i stonsko-korčulanskoga

100 "Et furono tutti huomini per tutto Stagno e Ponte della fede scismatica, che non credevano, nè Dio, nè Santi, ma credevano in sogni, indovini et incantatrici." Annales Ragusini Anonymi item Nicolai de Ragnina, str. 51. 
biskupa koji rješava Sveta Stolica. Dubrovčani, kako bi dobili ovaj spor, ističu svoje zasluge za katoličanstvo. Stanovnike Stona i Râta počinju nazivati "raskolnicima" predstavljajući Svetoj Stolici svoje zasluge za njihovo obraćenje. To isto čine i franjevci nakon što im je oduzeto pravo pastve u Stonu i Râtu. Za razliku od Dubrovčana i franjevaca stonskokorčulanski biskupi u njima nisu vidjeli raskolnike. Vjernici Stona i Râta zbog nemirnih političkih prilika i nebrige pastira svakako su bili vjerski zapušteni tako da se njihova zapuštenost mogla prikazati kao "raskolništvo" i kasnije kao "hereza". 


\section{Religious situation in the Hum land (Ston and Rat) during the Middle Ages}

\section{Summary}

The area of the Hum land was by the end of the 12th century in the jurisdiction of the Ston Catholic bishop. Beside Latin, Slavic, being dominant in this region, was also used in liturgy. As the diocese was situated at the crossroads of the East and the West, there was a "mixture" of the Western and Eastern rites. At the end of the 12th century, when the Hum land came under the rule of Prince Miroslav Nemanjic, the bishop of Ston was exiled. With the establishment of the Serbian Orthodox Archbishopric in 1219 these areas came under the influence of the Eastern Church. Its founder Rastko (Sava) Nemanjic appointed an episcope in Ston who recognized his jurisdiction and established the Hum episcopate. On the ground, things did not change due to the closeness of languages and church rites. There were no clashes over the church rites. The Bishop of Hum in Ston and Rat, and the Benedictines of the monastery of St. Mary on Mljet coexisted in this area. Due to unstable political situation the Bishop of Hum in the mid-13th century moved the seat of the eparchy to the monastery of St. Peter in Lim. In the mid 80s the appointment of the bishops of Ston was renewed. The Catholic Church recognized the diversity of languages and rites so that Catholic bishop and eastern "Raska" monks and priests, who celebrated the service in the Slavic language and, probably, eastern rites, could coexist again. When Ston and Rat fell under the rule of Dubrovnik, a major change occurred. Dubrovnik wanted to see the residents of Ston and Rat more tied to the Republic and blocked the Ston-Korcula bishop's jurisdiction in Ston and Rat bringing the priests and friars (foreigners?) from Bosnian vicariate, who introduced "Roman" rites and Latin in liturgy. It caused a conflict between Dubrovnik and the Ston-Korcula's bishops, which was resolved by the Holy See. Dubrovnik, in order to win this dispute, took all the credit for Catholicism. They even labeled the residents of Ston and Rat as "schismatics" representing thus to the Holy See the credit of Dubrovnik in their conversion. The same was done by the Franciscans after they were deprived of their congregation in Ston and Rat. Unlike Dubrovnik and the Franciscans, the bishops of Ston and Korcula did not see them as schismatic. Believers in Ston and Rat because of the turbulent political situation and the lack of care of their shepherds were certainly religiously neglected so that such negligence could be characterized as "schismatic" and later as "heretic".

Keywords: Hum, the Diocese of Ston, the Hum eparchy, western and eastern rites, Catholicism and Orthodoxy. 